Review

\title{
Co-Application of Charcoal and Wood Ash to Improve Potassium Availability in Tropical Mineral Acid Soils
}

\author{
Puvan Paramisparam ${ }^{1}$, Osumanu Haruna Ahmed ${ }^{1,2,3, *} \mathbb{C}$, Latifah Omar ${ }^{1,2}$, Huck Ywih Ch'ng ${ }^{4} \mathbb{1}$, \\ Prisca Divra Johan ${ }^{1}\left[\right.$ and Nur Hidayah Hamidi ${ }^{1}[$ \\ 1 Department of Crop Science, Faculty of Agricultural Science and Forestry, Bintulu Sarawak Campus, \\ Universiti Putra Malaysia, Bintulu 97008, Malaysia; puvanify@gmail.com (P.P.); \\ latifahomar@upm.edu.my (L.O.); prisca.divra@gmail.com (P.D.J.); dayahmidi@gmail.com (N.H.H.) \\ 2 Institut Ekosains Borneo (IEB), Faculty of Agriculture and Forestry Sciences, Bintulu Sarawak Campus, \\ Universiti Putra Malaysia, Bintulu 97008, Malaysia \\ 3 Institute of Tropical Agriculture, Universiti Putra Malaysia (ITAFoS), Seri Kembangan 43400, Malaysia \\ 4 Faculty of Agro-Based Industry, Jeli Campus, Universiti Malaysia Kelantan, Jeli 17600, Malaysia; \\ huckywih@umk.edu.my \\ * Correspondence: osumanu@upm.edu.my; Tel.: +60-19-3695095
}

Citation: Paramisparam, P.; Ahmed, O.H.; Omar, L.; Ch'ng, H.Y.; Johan,

P.D.; Hamidi, N.H. Co-Application of Charcoal and Wood Ash to Improve Potassium Availability in Tropical Mineral Acid Soils. Agronomy 2021, 11, 2081. https://doi.org/10.3390/ agronomy11102081

Academic Editor: Tim Weaver

Received: 20 July 2021

Accepted: 10 September 2021

Published: 18 October 2021

Publisher's Note: MDPI stays neutral with regard to jurisdictional claims in published maps and institutional affiliations.

Copyright: (c) 2021 by the authors. Licensee MDPI, Basel, Switzerland. This article is an open access article distributed under the terms and conditions of the Creative Commons Attribution (CC BY) license (https:// creativecommons.org/licenses/by/ $4.0 /)$.
Abstract: Potassium $(\mathrm{K})$ is a macronutrient required by plants for energy production, enzyme activation, formation of cell wall, production of protein, and photosynthesis. However, $\mathrm{K}$ in the soil solution is leached from the rhizosphere before it interacts with soil colloids because of the abundance of kaolinite clay minerals in mineral acid soils such as Ultisols and Oxisols. These soils are highly weathered, low in organic matter, low in $\mathrm{pH}$, but high aluminium ( $\mathrm{Al})$, and iron (Fe) ions. As a result, $\mathrm{K}$ becomes unavailable for plants, and this affects crop production and farmers' profitability. This problem has steered the attention to the application of amendments to minimise $\mathrm{K}$ loss. Animal manures, plant residues, and composts applications are some of the corrective measures taken to improve the $\mathrm{K}$ availability in tropical acid soils. However, there is dearth of information on co-application of charcoal and wood ash as soil amendments to improve the $\mathrm{K}$ availability and the changes they cause to the dynamic equilibrium of $K$ in mineral acid soils. Hence, this review discusses the dynamics, availability of $K$, and proposed mechanisms involved when charcoal and wood ash are used to amend tropical acid soils. The optimisation and understanding of the role of charcoal and wood ash co-application as soil amendments have potential benefits to improve the $\mathrm{K}$ availability and physicochemical properties of mineral acid soils.

Keywords: deprotonation; chelation; sorption capacity; functional groups; kaolinite; neutralising compounds; leaching

\section{Introduction}

The efficacy of chemical potassic fertilizers in nourishing plant needs are often compromised because most of the nutrients from fertilizers are commonly lost via leaching. Loss of plant nutrients is common in tropical mineral acid soils partly because of a high rainfall intensity and abundance of kaolinite clay minerals. This causes an unavailability of $\mathrm{K}$ in the soil for plant uptake. In general, tropical acid soils have low available nutrients because of extensive soil weathering, relatively high temperature, and annual rainfall. Highly weathered soils are high in $\mathrm{Al}^{3+}$ and $\mathrm{Fe}^{2+}$ because of their low $\mathrm{pH}[1,2]$. These ions are adsorbed onto the soil exchange complexes through replacement of $\mathrm{H}^{+}$. This cation exchange causes the release of $\mathrm{H}^{+}$ions into the soil solution (deprotonation). The $\mathrm{Al}^{3+}$ and $\mathrm{Fe}^{2+}$ are also able to displace base cations, one of which is $\mathrm{K}^{+}$, from the soil exchange complexes. When this occurs, it is difficult for $\mathrm{K}$ to be retained in the soil. Additionally, this cation exchange causes $\mathrm{Al}^{3+}$ and $\mathrm{Fe}^{2+}$ to replace $\mathrm{Ca}^{2+}, \mathrm{Mg}^{2+}$, and $\mathrm{Na}^{+}$into the soil solution; after which, they are lost through leaching. This chemical reaction causes a significant decrease in soil $\mathrm{pH}$, hence decreasing the reactivity of $\mathrm{K}$ in soils. 
As nutrient availability depends on soil $\mathrm{pH}$, farmers who grow crops on tropical acid soils resort to excessive fertilisation to replenish $\mathrm{K}^{+}$. However, the excessive use of chemical fertilisers will not benefit the agricultural sector, because this practice degrades the soil quality with time. Moreover, the K availability cannot be solved sustainably by the excessive use of chemical fertilizers. A viable option is to use organic amendments such as charcoal and wood ash to reverse the aforementioned problem by dealing with the soil condition itself. Apart from soil $\mathrm{pH}$, the soil texture, cation exchange capacity (CEC), and organic matter could be improved to increase the nutrient availability [3-6]. The perspective of agriculture and nutrient management has shifted to the use of organic amendments such as manures, plant residues, composts, and agro-industrial waste [7,8]. The application of organic amendments could improve the soil conditions (soil physicochemical properties), thus enhancing the $\mathrm{K}$ availability. The adoption of organic amendments in crop cultivation could increase soil CEC because of the high content of organic matter. Although there is evidence on organic amendments' capability in increasing the nutrient availability [9-12], there is dearth of information on improving the $\mathrm{K}$ availability of mineral tropical acid soils using charcoal and wood ash.

The utilisation of charcoal as a soil amendment is promising, because it provides reactive negatively charged surfaces, which enhance nutrient holding in the synchrony of crop nutrient uptake and, at the same time, chelating acidic cations such as $\mathrm{Al}^{3+}$ and $\mathrm{Fe}^{2+}$, which have been implicated in phosphorus (P) fixation [13-15]. Additionally, $\mathrm{Al}^{3+}$ and $\mathrm{Fe}^{2+}$ cause $\mathrm{H}^{+}$build up in mineral soil, because their hydrolysis releases $\mathrm{H}^{+}$. For example, for every mole of $\mathrm{Al}^{3+}$ that undergoes complete hydrolysis, three $\mathrm{H}^{+}$are released, and for $\mathrm{Fe}^{2+}$, two $\mathrm{H}^{+}$are released. Upon applying charcoal to soils, it decomposes to produce organic compounds [16] to bind $\mathrm{Al}^{3+}$ and $\mathrm{Fe}^{2+}$. At the same time, the $\mathrm{pH}$ of soils needs to be increased to ensure base cations such as $\mathrm{K}$ are more reactive and available for plants. Most wood ash has a high $\mathrm{pH}$. The $\mathrm{pH}$ of wood ash ranges between 8.9 and 13.5 [17]. It was also reported that application of wood ash can neutralise soil acidity and $\mathrm{Al}^{3+}$ and $\mathrm{Fe}^{2+}[18,19]$. With these aspects in focus, the utilisation of charcoal and wood ash could be pivotal in improving the physicochemical properties and $\mathrm{K}$ availability of tropical acid soils. Therefore, it is hypothesised that the combined use of potassic fertilizers, charcoal, and wood ash in tropical acid soils could improve the $\mathrm{K}$ availability because of their acid, $\mathrm{Al}^{3+}$, and $\mathrm{Fe}^{2+}$ neutralizing effects. The high CEC of charcoal and sago bark ash could further enhance the $\mathrm{K}$ availability because of their ability to temporarily retain $\mathrm{K}^{+}$. Therefore, the objectives of this review were to (i) discuss the dynamics and availability of $\mathrm{K}$ in tropical acid soils and (ii) propose possible mechanisms involved when charcoal and wood ash used to amend potassic fertilisers in tropical mineral acid soils.

\section{Development of Soil Acidity}

Approximately half of Earth's arable land is acidic, and approximately $60 \%$ of it occurs in the tropics and subtropics [20]. Acidity develops in soils for several natural and anthropogenic factors. Soil acidity is attributed to atmosphere, rainwater, mineral weathering, mineral transformation, decomposition of organic residues, microbes, root respiration, root secretion, and the release of hydrogen ions in exchange of bases. Additionally, the excessive use of chemical fertilizers in particular has been implicated in the occurrence of soil acidity. Moreover, the development of soil acidity is associated with organic and inorganic acids; the replacement of base cations by $\mathrm{H}^{+}, \mathrm{Al}^{3+}, \mathrm{Fe}^{2+}$; and the leaching of bases.

Acid rain is the primary cause of soil acidification in the soils of highly industrialised regions [21]. Rainwater becomes acidic because of the dissolution of atmospheric carbon dioxide $\left(\mathrm{CO}_{2}\right)$, which undergoes a reaction as presented in chemical Equations (1)-(3).

$$
\begin{gathered}
\mathrm{H}_{2} \mathrm{O}+\mathrm{CO}_{2} \rightarrow \mathrm{H}_{2} \mathrm{CO}_{3} \\
\mathrm{H}_{2} \mathrm{CO}_{3} \rightarrow \mathrm{HCO}_{3}{ }^{-}+\mathrm{H}^{+} \\
\mathrm{HCO}_{3}{ }^{-} \rightarrow \mathrm{CO}_{3}{ }^{2-}+\mathrm{H}^{+}
\end{gathered}
$$


Rainwater in equilibrium with atmospheric $\mathrm{CO}_{2}$ has a $\mathrm{pH}$ approximately 5.5 unless it contains dissolved bases. Similarly, the formation of carbonic acid occurs in soil water because $\mathrm{CO}_{2}$ is produced by atmospheric diffusion, the decomposition of organic residue, and root and microbial respiration [22]. The rate of carbonic acid formation may differ with climate and vegetation. Likewise, sulphur and nitrogen oxides in the atmosphere form acids in rainwater, as presented in chemical Equations (4)-(6).

$$
\begin{gathered}
\mathrm{NO}+1 / 2 \mathrm{O}_{2} \rightarrow \mathrm{NO}_{2} \\
3 \mathrm{NO}_{2}+\mathrm{H}_{2} \mathrm{O} \rightarrow 2 \mathrm{HNO}_{3}+\mathrm{NO} \\
\mathrm{SO}_{2}+\mathrm{H}_{2} \mathrm{O} \rightarrow \mathrm{H}_{2} \mathrm{SO}_{3}
\end{gathered}
$$

In the humid tropics, soils experience intensive weathering and leaching, during which minerals are decomposed because of weathering and the soluble products are removed by leaching [23]. Low-activity 1:1 clay minerals such as kaolinite, in addition to iron and aluminium oxides or sesquioxides, dominate the finer fraction of the soils with kaolinite. These soils have low buffering capacities, because they have low CEC and base saturation percentages (BSP). As a result, they are commonly acidic. These characteristics are noticed in Oxisols and Ultisols. Aluminium ions are adsorbed on exchange complexes via hydrolysation, generating hydrogen ions as products. For a mole of $\mathrm{Al}^{3+}$ that undergoes complete hydrolysis, three $\mathrm{H}^{+}$are released, as demonstrated in chemical Equations (7)-(10). The hydrogen ion replaces bases that are absorbed to cause soil acidity [24].

$$
\begin{gathered}
\mathrm{Al}^{3+}+\mathrm{H}_{2} \mathrm{O} \rightarrow \mathrm{Al}(\mathrm{OH})^{2+}+\mathrm{H}^{+} \\
\mathrm{Al}(\mathrm{OH})^{2+}+\mathrm{H}_{2} \mathrm{O} \rightarrow \mathrm{Al}(\mathrm{OH})_{2}{ }^{+}+\mathrm{H}^{+} \\
\mathrm{Al}(\mathrm{OH})_{2}{ }^{+}+\mathrm{H}_{2} \mathrm{O} \rightarrow \mathrm{Al}(\mathrm{OH})_{3}+\mathrm{H}^{+} \\
\mathrm{Al}^{3+}+3 \mathrm{H}_{2} \mathrm{O} \rightarrow \mathrm{Al}(\mathrm{OH})_{3}+3 \mathrm{H}^{+}
\end{gathered}
$$

Base cations such as Calcium (Ca) and magnesium $(\mathrm{Mg})$ are leached from the soil in regions with high rainfall triggering its acidification.

Apart from carbonic acid, inorganic acids such as nitric, hydrochloric, and sulfuric acids may be produced in soils and become accountable for the acidification of soils. Sulphur oxidation is a significant reaction of inorganic acidification in soils. In some areas such as mine spoils, mangrove swamps, and estuarine areas, pyrite $\left(\mathrm{FeS}_{2}\right)$ is high in their soils [25]. Pyrite oxidizes to produce sulphuric acid, and this compound decreases the soil $\mathrm{pH}$. The rapid decrease in $\mathrm{pH}$ is because of two hydrogen ions that are produced for every sulphur ion being oxidized, as demonstrated in Equation (11). Soils facing this problem are known as acid sulphate.

$$
2 \mathrm{FeS}_{2}+7 \mathrm{O}_{2}+6 \mathrm{H}_{2} \mathrm{O} \rightarrow 4 \mathrm{SO}_{4}{ }^{2-}+8 \mathrm{H}^{+}+2 \mathrm{Fe}(\mathrm{OH})_{2}
$$

Atmospheric deposition and canopy throughfall contribute to a small portion of organic acids in the soil. Greater amounts of organic acids come from root exudation, lysis in addition to the release of microorganisms [26]. The decomposition of rice straw produces citric, oxalic, formic, and malic acids [27]. Although how these acids influence soil acidity has not been studied, citric and oxalic acids are known to affect the solubilisation of phosphorus (P) from Ca phosphate and rock phosphate.

Organic matter in different forms also leads to soil acidification. This depends on plants from which the organic matter originates. For example, some plant residues have low bases. Hence, the cultivation of such crops without sustainable soil management for a long time causes soil acidity. In other words, plants or vegetation play a major role in affecting the $\mathrm{pH}$ of soils. Soil $\mathrm{pH}$ could decrease or increase depending on the removal of cations and anions from the soil. Legumes can be used as an analogy for the case of soil acidification. This is related to the fact that legumes take up more cations compared 
with anions. Leguminous plants consume a small amount of nitrate $\left(\mathrm{NO}_{3}{ }^{-}\right)$from the soil, because microbial nitrogen $(\mathrm{N})$ fixation within the plant structure makes up for most of the $\mathrm{N}$ requirement [28]. Additionally, fertilisers cause soil acidity. Nitrogen fertilisers with ammonium $\left(\mathrm{NH}_{4}{ }^{+}\right)$release hydrogen ions to the soil as ammonium are converted to nitrate, as demonstrated in the chemical Equation (12).

$$
\mathrm{NH}_{4}{ }^{+}+2 \mathrm{O}_{2} \rightarrow \mathrm{NO}_{3}{ }^{-}+2 \mathrm{H}^{+}+\mathrm{H}_{2} \mathrm{O}
$$

In Equation (12), the conversion of one mole of ammonium ion to nitrate produces two hydrogen ions. As an example, urea $\left[\mathrm{CO}\left(\mathrm{NH}_{2}\right)_{2}\right]$ decomposes when the soil $\mathrm{pH}$ is below 6.3 (Equation (13)).

$$
\mathrm{CO}\left(\mathrm{NH}_{2}\right)_{2}+2 \mathrm{H}^{+}+2 \mathrm{H}_{2} \mathrm{O} \rightarrow 2 \mathrm{NH}_{4}^{+}+\mathrm{H}_{2} \mathrm{CO}_{3}
$$

Although this chemical reaction uses two hydrogen ions, the overall reaction is acidifying, because the decomposition of urea produces two ammonium ions. Thereafter, these ions are converted to nitrate, generating four hydrogen ions [29]. As for phosphate fertilizers, triple superphosphate and monocalcium phosphate $\left[\mathrm{Ca}\left(\mathrm{H}_{2} \mathrm{PO}_{4}\right)_{2}\right]$ are commonly applied to soils. Dicalcium phosphate $\left(\mathrm{CaHPO}_{4}\right)$ and phosphoric acid $\left(\mathrm{H}_{3} \mathrm{PO}_{4}\right)$ are formed when phosphate fertilisers react with water in soils. The latter product further breaks down to produce hydrogen ions, as demonstrated in chemical Equations (14) and (15).

$$
\begin{gathered}
\mathrm{Ca}\left(\mathrm{H}_{2} \mathrm{PO}_{4}\right)^{2}+\mathrm{H}_{2} \mathrm{O} \rightarrow \mathrm{CaHPO}_{4}+\mathrm{H}_{3} \mathrm{PO}_{4} \\
\mathrm{H}_{3} \mathrm{PO}_{4} \rightarrow \mathrm{H}^{+}+\mathrm{H}_{2} \mathrm{PO}_{4}{ }^{-} \rightarrow 2 \mathrm{H}^{+}+\mathrm{HPO}_{4}{ }^{2-} \rightarrow 3 \mathrm{H}^{+}+\mathrm{PO}_{4}{ }^{3-}
\end{gathered}
$$

This reaction causes soil to be acidic. Although phosphorous (P) fertilisers are commonly placed in bands around crop rows, the hydrogen ions slowly disperse throughout the soil causing progressive acidification of a particular soil. Moreover, characteristics of parent materials are major components that determine the soil acidity. They include type, texture, composition, and the level of weathering. Acidic parent materials such as granites, rhyolites, and diorites have greater fractions of quartz, feldspar, and sesquioxide minerals [30]. Lower base cations make these types of soil more acidic and less fertile for cropping.

In acidic conditions, the availability of plant nutrients such as $\mathrm{N}, \mathrm{P}, \mathrm{K}, \mathrm{S}, \mathrm{Ca}, \mathrm{Mg}$, and molybdenum is compromised (Figure 1). In addition, nutrients could be positionally less available because of poor root growth in acidic soils as a result of $\mathrm{Al}$ and Fe toxicity. When root growth is restricted, plants are unable to explore sufficient soil volume to compensate for the reduced availability. Besides, at low $\mathrm{pH}, \mathrm{Al}$ and $\mathrm{Fe}$ tend to displace $\mathrm{K}^{+}$from soil colloids. The removal of $\mathrm{K}^{+}$ions from the colloids increases their loss through leaching [31]. Hence, more $\mathrm{K}$ fertilizers would be required for optimal plant growth.

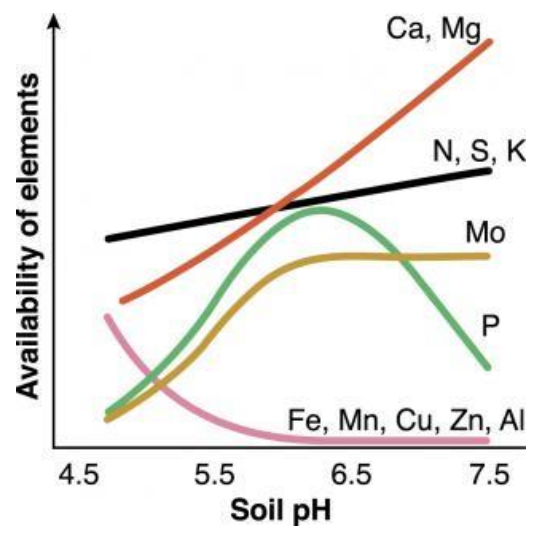

Figure 1. Nutrient availability in relation to soil $\mathrm{pH}$ [32]. 


\section{Acidic Mineral Soils}

Ultisols and Oxisols are the two dominant soils in the tropics. Ultisols and Oxisols occur as result of the intense and prolonged weathering of shale, granite, sandstone, schist, serpentinite, basalt, and andesite [33]. Typically, Ultisols originate from the weathering of shale and sandstone, whereas Oxisols occur from shale schist [34]. The products of weathering include kaolinite (dominant clay fraction), halloysite, gibbsite, goethite, and hematite in the clay fraction [35].

Ultisols and Oxisols are mostly infertile and have low CEC because of their $\mathrm{pH}$ (4 to 5). They are composed of kaolinite and sesquioxides (oxides of Fe and Al), which are prone to K leaching [33] (Figure 2). To make these soils arable, liming and fertilisation are required. Ultisols have more sesquioxides and higher exchangeable $\mathrm{Al}$ compared with Oxisols, because they are extensively weathered. This causes Ultisols to be acidic, thus having lower $\mathrm{pH}$ and exchangeable bases compared to Oxisols [31]. Hence, Ultisols and Oxisols require the addition of organic matter-rich amendments to increase the CEC of these soils, which are inherently low in organic matter [34].

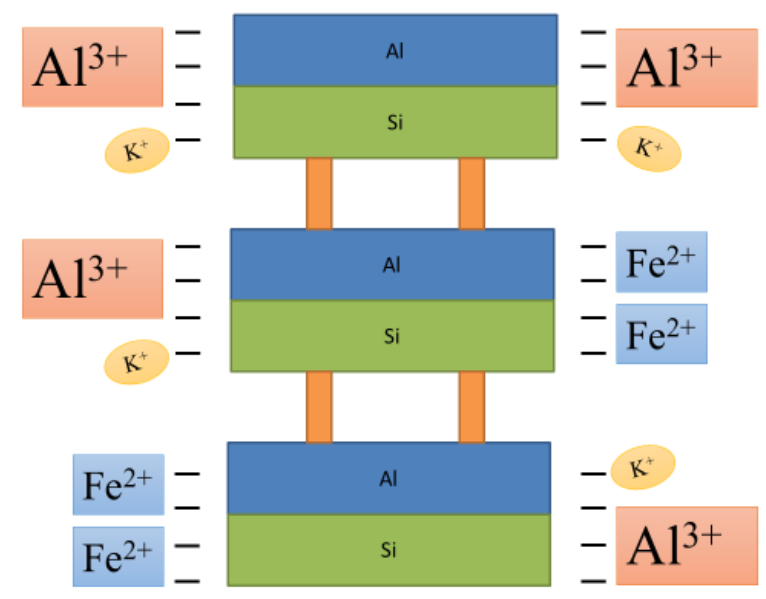

Figure 2. Conceptualisation of kaolinite's low negative charge density and high level of aluminium and iron ions in acid soils, hindering potassium ion retention.

\section{Clay Mineralogy of Tropical Soils}

Soils in the tropics are classified into four different clay mineralogy [36]. The soil clay minerals consist of kaolinitic, oxidic, allophanic, and smectitic soil. The occurrence of these clay mineral is in the following order of: kaolinitic soils > oxidic soils > smectitic soils $>$ allophanic soils [37]. Nonetheless, in terms of agricultural potential, the order is: allophanic = smectitic soils $>$ oxidic soils $>$ kaolinitic soils.

\subsection{Kaolinitic Soils}

Kaolinitic soils are severely weathered and have either sand, loamy sand, or sandy loam textures on the surface [38]. Clayey texture usually ranges from 20 to $60 \%$ in the B horizon. Kaolinitic soils have low CEC $\left(<12 \mathrm{cmol} \mathrm{kg}^{-1}\right)$ and high bulk density $[39,40]$. Although kaolinitic soils have good water percolation under natural vegetation, they are less permeable when cultivated with crops. The major constraint in these soils is soil erosion, compaction, and the leaching of base cations [41]. Kaolinite is the predominant mineral in kaolinitic soils, because they make approximately $90 \%$ of the clay fractions $[42,43]$. Kaolinite is the simplest layer silicate (1:1 lattice). It is made up by a union of one tetrahedral sheet with an octahedral sheet. The layers are neutral in charge, except for the broken bonds at the crystal edges. These broken bonds serve as nutrient holding sites, despite low amount. Kaolinite minerals form thick layers because of hydrogen bonding [44]. Hydrogen from the hydroxyl ions of the octahedral sheet of one kaolinite layer is attracted to the free oxygen in the tetrahedral sheet of another kaolinite layer. As a consequence of the strong hydrogen bond, many layers are stacked together. This prevents water and nutrients from entering 
between the layers [44]. Hence, kaolinite has low CEC, and it is hard to swell or shrink, depending on the wetness or dryness of the soil (nonexpanding clay). In addition, the low negative charge density of kaolinite results in the leaching of base cations from soil [45].

\subsection{Oxidic Soils}

Oxidic soils are highly weathered red and yellowish soils. These soils have fine texture and low bulk density [46]. Similar to kaolinitic soils, kaolinite is the predominant clay mineral in oxidic soils. However, clay sized iron oxides and hydrous oxides provides these soils with stable soil structure and lower bulk density, unlike kaolinitic soils. Red and yellow distinguish the dominance of high surface area hematite (red oxidic soil) or high specific surface area goethite. The effective CEC of oxidic soils is $12 \mathrm{cmol}$ or less per $\mathrm{kg}$ clay [47]. These soils have $\mathrm{pH}$ ranging from 4.3 to 5.7 and CEC of 2.23 to $3.06 \mathrm{cmol} \mathrm{kg}^{-1}$ [48]. Soil management constraints when using oxidic soils for crop production are a low waterholding capacity, low nutrient reserve, and high phosphate fixation causing a deficiency of available P for plant uptake $[49,50]$.

\subsection{Smectitic Soils}

Smectitic soils are alluvial soils that are loamy to clayey. These soils contain $30 \%$ or more smectite clay mineral in the clay fraction. The $\mathrm{pH}$ of smectitic soils ranges from 6.3 to 6.7 [48]. Smectite clay minerals shrink and swell, depending on the soil wetness or dryness [51,52]. There is also the presence of other 2:1-layer silicate minerals (illite, vermiculite, and chlorite) and 1:1-layer silicate (kaolinite) in small amounts in the clay fraction of these soils. Smectitic soils have moderately high CEC, ranging between 10 and $50 \mathrm{cmol} \mathrm{kg}^{-1}$ [53-55]. As a result, these soils have a high base saturation and water-holding capacity [56]. Smectitic soils are regarded as the best soil for rice cultivation [57]. Smectite clay mineral is formed via the union of two tetrahedral sheets with one octahedral sheet. The two tetrahedral sheets are held on opposite sides of the octahedral sheet. The absence of hydrogen bonding to lock layers of smectite together [58] enables water and nutrients to enter in between the layers. Smectites have a large negative charge density, enabling the attraction of cations to their surfaces. Nevertheless, the forces of attraction are not very strong, enabling displacement of the cations. The loosely held cations are known as exchangeable cations, which serve as a nutrient reserve in the soil system [59].

\subsection{Allophanic Soils}

Allophanic soils are young soils that are dark in colour, and they originate from volcanic ash. Allophanic soils are fertile; yet, they are only found in regions with active volcanoes [60]. The traits of these soils are a low bulk density and high-water holding capacity. The $\mathrm{pH}$ of these soils ranges from 4.8 to 5.7 [48]. Allophanic soils are predominated by allophones, imogolite, halloysite, and amorphous aluminium silicate in the clay fraction [61].

\section{Soil Factors Affecting Nutrient Availability}

The nutrient availability in the soils is regulated by several soil factors such as the texture, $\mathrm{CEC}, \mathrm{pH}$, and organic matter.

\subsection{Soil Texture}

The relative proportion of sand, clay, and silt in soils is known as the soil texture [62]. The soil texture is closely associated with the movement and the retention of soil water [63]. Since most available nutrients for plants exist in the soil solution, the soil texture has a direct influence on soil nutrient retention. Sandy soils have large pores and a poor water-holding capacity. In such soils, leaching occurs rapidly, and the soils are unable to hold nutrients for the optimum plant uptake $[64,65]$. In contrast to sandy soils, clayey soils can hold water and nutrients because of the smaller pores and charged surfaces. Smaller pores provide these soils with high net charges that act as nutrient-binding sites [63]. 


\subsection{Soil $p H$}

Soil $\mathrm{pH}$ serves as a scale to determine the acidity or alkalinity of soils. Soil $\mathrm{pH}$ enables the determination of hydrogen ions $\left(\mathrm{H}^{+}\right)$in soils, specifically in the soil solution [66]. In general, soil $\mathrm{pH}$ ranges between 4 and 8 [67], where $\mathrm{pH} 4$ is strongly acidic and $\mathrm{pH} 8$ is basic. Soil $\mathrm{pH}$ contributes to nutrient availability in several ways. The $\mathrm{pH}$ of a soil regulates the degree of weathering and dissolution of materials in soils. In addition, soil $\mathrm{pH}$ is directly related to the CEC of soils, because it affects the surface charge of soil colloids [68]. For example, at a low $\mathrm{pH}$, where the $\mathrm{H}^{+}$concentration is high, the negative charges on soil colloids are neutralised. As a result, acidic soils often experience nutrient deficiency. In the case of $\mathrm{N}$, the mineralisation rate of the element from organic matter is rapid when the soil $\mathrm{pH}$ is in the range of 6-8. Likewise, $\mathrm{pH} 6.5-7.5$ is the range where $\mathrm{P}$ is readily available for plants. In acidic soils, iron and aluminium fix $\mathrm{P}$, hence rendering $\mathrm{P}$ unavailable for plants. On the other hand, at high $\mathrm{pH}, \mathrm{Ca}$ phosphates are formed. Potassium leaching occurs extensively in acidic soils, because the soil colloids in such soils have very low negative charges. Similar to $\mathrm{P}, \mathrm{K}$ becomes unavailable at high $\mathrm{pH}$ because of the antagonistic effects of $\mathrm{Ca}$ and $\mathrm{Mg}$ [69].

\subsection{Soil Organic Matter}

Any organic material in soils is considered a soil organic matter [70]. These organic materials may vary in terms of the origin and decomposition rate. Organic matter contains many proteins, carbohydrates, amino acids, fatty acids, and organic acids with low molecular weights [71]. All these can be degraded through microbial activity and serve as nourishments for plants. The high CEC (150-300 $\left.\mathrm{cmol} \mathrm{kg}^{-1}\right)$ enables organic matter to retain nutrients in the soil. Besides that, soil organic matter improves the soil aggregation and water-holding capacity by reducing the soil bulk density; thus, the loss of nutrients through leaching can be minimised [72].

\subsection{Soil Cation Exchange Capacity}

The soil cation exchange capacity is the sum of the ability of soil to adsorb exchangeable cations on its colloidal constituents [66]. As the definition, the CEC of soil is related to soil colloid. In addition, CEC is closely related to $\mathrm{pH}$, where the CEC increases with the increasing soil $\mathrm{pH}$ [73]. Soils with low CEC have a poor nutrient retention capacity. This is more notable when such soils experience large volumes of precipitation. Most of the cations in the A horizon are leached, causing nutrient deficiencies [68]. The cation exchange capacity is essential in creating a mechanism of ion exchange in soil to make nutrients available for plant uptake. The displacement of nutrient cations $(\mathrm{Ca}, \mathrm{Mg}$, and $\mathrm{K})$ from the exchange complex by $\mathrm{H}^{+}$enables the release of these cations to move into soil solution and, therefore, are absorbed by plants [74].

\section{Potassium and Its Importance to Plants}

Potassium is a macronutrient required by plants [75]. Potassium is the second-most abundant plant nutrient and, also, a non-renewable resource. In general, $\mathrm{K}$ is essential for cellular energy production, osmoregulation via the control of stomatal function, enzyme activation, formation of the cell wall, production of proteins, and photosynthesis. In most horticultural crops, $\mathrm{K}$ boosts plant ontogeny [76]. Moreover, $\mathrm{K}$ contributes to the colour, shape, size, taste, texture, shelf life, and processing characteristics of fruit and vegetable plants [77]. For example, a higher $\mathrm{K}$ content increases the content of vitamin $\mathrm{C}$ and improves the utilisation of $\mathrm{N}$ [78]. In this way, it influences protein formation in plants. Potassium is not only an integral component of transport in plants, it also increases the oil content in plants $[79,80]$. Furthermore, $\mathrm{K}$ plays vital role in some plant growth aspects, such as the smooth progress of cell division and growth, increase of disease resistance, and tolerance to drought (stomatal regulation) [81]. Potassium is required by plants in comparatively larger amounts compared with other essential plant nutrients [82]. Brady and Weil [31] asserted that plants absorb K approximately five to ten times as much as P. 
Potassium is extracted in large quantities by intensive cropping systems extracting large amount of K [83] and, thus, leading to extensive application in most agricultural areas [84].

\section{Potassium Dynamics in Soil}

Soil $\mathrm{K}$ is categorised into water-soluble $\mathrm{K}$, exchangeable $\mathrm{K}$, nonexchangeable $\mathrm{K}$, and mineral $\mathrm{K}$ or fixed $\mathrm{K}[85,86]$. Water-soluble $\mathrm{K}$ are $\mathrm{K}$ source that are readily available for plant uptake. Exchangeable $\mathrm{K}$ are $\mathrm{K}$ reserve that are easily mobilized. Both water-soluble $\mathrm{K}$ and exchangeable $\mathrm{K}$ are plant available $\mathrm{K}$, and they make up approximately 1 to $2 \%$ of the soil total $\mathrm{K}$ [31]. On the other hand, nonexchangeable $\mathrm{K}$ is poorly mobilized in soil and takes a long time to be available for plants. Similarly, mineral $\mathrm{K}$ is $\mathrm{K}$ that is inert and unweathered in soil. In tropical acid soils such as Ultisols and Oxisols, the bioavailability of $\mathrm{K}$ is extremely low due to intense weathering and constant leaching $[87,88]$. Besides, the weathering of sandstone usually produces soil that has low water-soluble $\mathrm{K}$, whereas soil originating from young volcanic rocks have a high content of the available $\mathrm{K}$ [87]. The order of the $\mathrm{K}$ availability is water-soluble $\mathrm{K}>$ exchangeable $\mathrm{K}>$ nonexchangeable $\mathrm{K}>$ mineral $\mathrm{K}[85,89]$. These $\mathrm{K}$ fractions correlate to an equilibrium system in soils and dynamically shift its direction to replenish itself when depleted [90]. Figure 3 demonstrates the interrelationships between the fractions of $\mathrm{K}$ in soils.

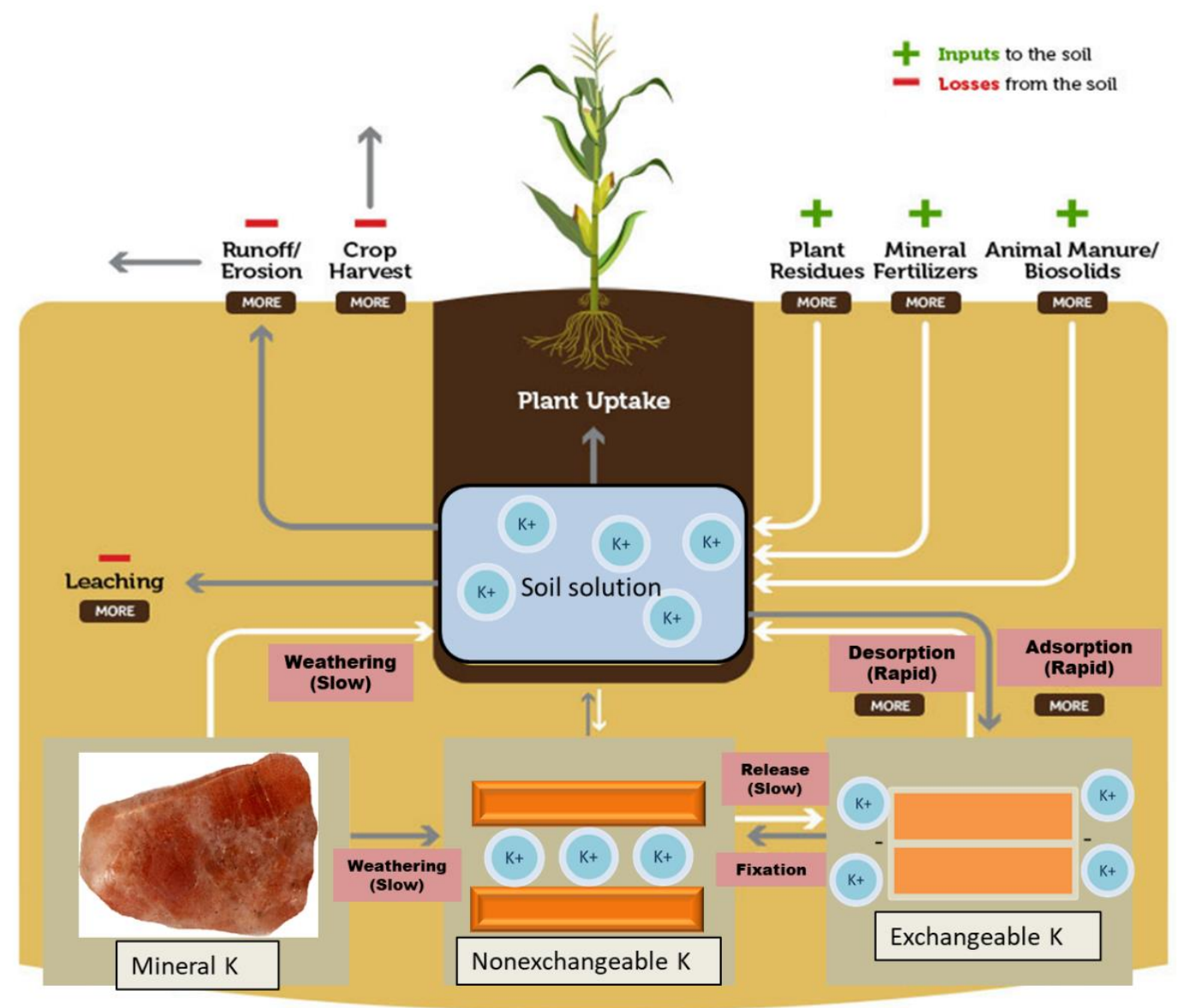

Figure 3. Interrelationships between various fractions of $\mathrm{K}$ in soils (adapted from Wang et al. [89]).

\subsection{Water-Soluble Potassium}

Water-soluble $\mathrm{K}$, also referred to as soil solution $\mathrm{K}$, is the $\mathrm{K}$ fraction that exist in soil water, and it is directly taken up by plants. Water-soluble $\mathrm{K}$ is usually very low in soils, thus leading to the need for $\mathrm{K}$ fertilization. The amount of water-soluble $\mathrm{K}$ depends on the equilibrium and kinetic reactions that takes place in all forms of soil K [91], soil moisture content [92], concentration of bivalent cations in solution, and the exchanger phase [93]. 
Additionally, water-soluble $\mathrm{K}$ can be replenished by the nonexchangeable $\mathrm{K}$ fractions. The reduction in water-soluble $\mathrm{K}$ pool initiates the movement of $\mathrm{K}$ from the nonexchangeable $\mathrm{K}$ reserve [94]. Leaching or removal by crop reduces the concentration of water-soluble $\mathrm{K}$ in soil. Additionally, the concentration of water-soluble $\mathrm{K}$ in soil is related to clay mineral buffering. A high $\mathrm{K}$ concentration in the soil solution creates a diffusion gradient to enable the movement of $\mathrm{K}$ into an actively absorbing root. Nevertheless, in most soils, watersoluble K only represents a minute proportion of the total soil K, which is lower than the crop requirement for a growing season.

\subsection{Exchangeable Potassium}

The exchangeable $\mathrm{K}$ is readily available to plants, and its name is derived from the ability of $\mathrm{K}$ in this fraction to be interchanged with other cations. The exchangeable $\mathrm{K}$ fractions are bound electrostatically at different strengths on the adsorption sites of clay minerals and humic substances. Exchangeable $\mathrm{K}$ are able to be adsorbed on carboxylic and phenolic groups of humus colloids, which are negatively charged, in addition to the planar or vertices of the clay minerals [95]. The factors that contribute to the amount of exchangeable $\mathrm{K}$ adsorbed on clay minerals may be either kinetic or thermodynamic factors [96]. The affinity of the adsorption sites for $\mathrm{K}$ depends on the nature of the soil surface, which determines the amount of the exchangeable $\mathrm{K}$ fractions. Besides, the $\mathrm{K}$ concentration near the adsorption sites in contrast to the concentration of other cations, especially bivalent cations, also affects the amount of the exchangeable $\mathrm{K}$ adsorbed.

\subsection{Nonexchangeable Potassium}

Nonexchangeable $\mathrm{K}$ is defined as interlayer $\mathrm{K}$ and slowly exchangeable or available $\mathrm{K}$ [97]. The main difference between nonexchangeable $\mathrm{K}$ and mineral $\mathrm{K}$ is that the former fraction is not bonded within the crystal structures of the soil mineral particles. Instead, nonexchangeable $\mathrm{K}$ is held or trapped between adjacent tetrahedral layers of clay minerals such as micas, vermiculites, and chloritized vermiculite. Nonexchangeable K can only be freed by a slow diffusion-controlled process, since $\mathrm{K}^{+}$ions are fixed in between the layers, because the high binding forces between the surfaces of the layers and $K$, which exceed the hydration forces between individual $\mathrm{K}^{+}$ions, can cause a partial collapse of the crystal structure. Moreover, the nonexchangeable $\mathrm{K}$ fraction can also be present in the wedge zones of weathered micas and vermiculites, and the $\mathrm{K}$ is displaced by cations with similar sizes to $\mathrm{K}^{+}\left(\mathrm{NH}^{4+}\right.$ and $\left.\mathrm{H}_{3} \mathrm{O}^{+}\right)$, because larger hydrated cations $\left(\mathrm{Ca}^{2+}\right.$ and $\left.\mathrm{Mg}^{2+}\right)$ do not fit into the wedge zones. The release of nonexchangeable $\mathrm{K}$ (to exchangeable form) is induced when there is decrease in the levels of exchangeable and soil solution $\mathrm{K}$ due to leaching or crop uptake $[98,99]$.

\subsection{Mineral Potassium}

Mineral $\mathrm{K}$ is also referred to as structural or fixed $\mathrm{K}$, which is an unweathered and inert form of K [100]. Parent materials and the age of soil are two factors that determine the mineral $\mathrm{K}$ proportion in soil [93]. The mineral $\mathrm{K}$ fraction is unavailable for plants and can only become available through the weathering of minerals, which proceeds extremely slow [85]. The rate of weathering of the primary minerals depends on the environment and the composition and structure of the minerals. Potassium in soils is mostly in the mineral fractions, because it exists in the primary minerals, including muscovite, biotite, and feldspar. They are bound covalently within the crystalline structure of these K-bearing minerals. Sometimes, weathered minerals generate secondary layer silicates, which can retain some of the mineral $\mathrm{K}[95,101]$.

\subsection{Potassium Fixation}

Potassium moves readily in submerged lowland rice soils, but it is not mobile in most soils. Compared to $\mathrm{N}$ and $\mathrm{P}, \mathrm{K}$ ions have less mobility compared with $\mathrm{N}$ but move more readily than the ions of $\mathrm{P}$ [102]. The type of soil clay mineral and the amounts of the mineral 
present and the soil CEC are the factors that determine the availability of $\mathrm{K}$ in a particular soil [100]. Potassium ions are highly fixed by illite, vermiculite, and montmorillonite compared with kaolinite [85,103], and this contradicts the P fixation where clays of 1:1 lattice tend to adsorb more $\mathrm{P}$ than those with 1:2 lattice in tropical soils. The potassium fixation begins when $\mathrm{K}$ ions are adsorbed on sites in the interlayers of weathered sheet silicates. Potassium fixation depends on the clay mineral type and charge density, moisture content, presence of competing ions, and soil $\mathrm{pH}$ [104]. The potassium fixation is crucial in preventing a total loss of $\mathrm{K}$ after fertilisation in tropical acid soils where leaching occurs drastically. The replenishment of water-soluble $\mathrm{K}$ from nonexchangeable $\mathrm{K}$ is induced when there is a drop in the concentration of $\mathrm{K}^{+}$in the soil solution because of leaching or crop removal [105]. Fixed $\mathrm{K}$ acts as a reservoir for $\mathrm{K}$ in soil. Soil wetting and drying enables the weathering of clay, which, in turn, enhances the release of $\mathrm{K}$ from nonexchangeable fractions [106]. Nevertheless, the release mechanism occurs slowly, and this is attributable to the strong binding forces between $\mathrm{K}^{+}$and clay minerals [107]. Hence, it is important to optimise the soil properties that favour cropping through the timely release of fixed $\mathrm{K}$ while preventing $\mathrm{K}$ leaching.

\subsection{Loss of Potassium through Leaching}

In Malaysia, high precipitation and temperature leads to the chemical weathering of Ultisols and Oxisols [33]. Irrigation also increases the rate of leaching of $\mathrm{K}$. Troeh and Thompson [67] stated that humid regions have low soil total and available K compared with the soils in arid regions. Potassium immobilisation occurs less frequently when the degree of weathering is higher. Kaolinite clay is common in highly weathered soils and its 1:1 lattice structure with relatively low charge density in its layers, causing the leaching of $\mathrm{K}$ to be more intense. Moreover, the CEC of kaolinite contributes to fewer storage sites for not only K but, also, other cations [108]. Quartz, secondary phyllosilicates, and sesquioxides with or without muscovite are formed when rocks and mineral weather in the humid tropics, and this depends on the intensity of weathering [34]. The dissolution of feldspar (orthoclase) in water causes $\mathrm{K}$ leaching [34]. The $\mathrm{K}$ ions in feldspars occur in spaces surrounded by tetrahedral but in a three-dimensional shape instead of layers. Potassium is released from the weathering of a potassium feldspar and is subsequently leached because of the low CEC of kaolinite.

$$
\begin{gathered}
6 \mathrm{H}_{2} \mathrm{O}+\mathrm{CO}_{2}+2 \mathrm{KAlSi}_{3} \mathrm{O}_{8} \rightarrow \mathrm{A1}_{2} \mathrm{Si}_{2} \mathrm{O}_{8}(\mathrm{OH})_{4}+4 \mathrm{SiO}(\mathrm{OH})_{2}+\mathrm{K}_{2} \mathrm{CO}_{3} \\
\text { (feldspar) (kaolinite) }
\end{gathered}
$$

Additionally, the leaching of $\mathrm{K}$ depends on clay content in soils and soil organic matter. The leaching of $\mathrm{K}$ is more prevalent in soils with lower clay and organic matter compared with soils with a higher clay content and amount of organic matter [69]. The leaching of soil solution K can increase the release of K from soil minerals [109], but the induction of this replenishment mechanism depends on the soil $\mathrm{pH}$, movement of $\mathrm{K}$ in soils, soil CEC, liming, and rate of $\mathrm{K}$ uptake by plants and microbes [35,87]. The loss of $\mathrm{K}$ through leaching can be managed by practicing good erosion control measures (cover crop, mulching, contour farming, reforestation, conservative tillage, and wind breakers); the improvement of soil $\mathrm{pH}$ (in acidic soil); enhancing soil CEC using organic amendments such as animal manures, plant residues, or composts; and split applications of $\mathrm{K}$ fertilizers according to the plant growth stage [110].

\section{Sources and Role of Organic Amendments on Nutrient Availability}

Commercial mineral fertilisers have high solubility, which eases the nutrient uptake of plants. However, the extensive applications of chemical fertilisers cause soil degradation, environmental pollution, and loss of biodiversity. For example, the leaching of excess nutrients from chemical fertilisers causes groundwater contamination and affects the human consumption of clean water [111]. Biosolids, animal manures, municipal solid 
waste, plant residues, forest litter, leguminous trees, seaweeds, and blood and bone meals are examples of organic amendments used in agriculture [112-114]. With the increasing global demand for energy production and cost of inorganic fertilisers, the utilisation of organic amendments will be able to compensate the nutrient deficiency in addition to ensuring the sustainability of agricultural lands [7,8]. Additionally, the utilisation of organic amendments is reported to improve the soil carbon content, microbial activity, and agronomic benefits [115].

\subsection{Animal Manures}

Animal manure directly supplies nutrients such as $\mathrm{K}, \mathrm{P}$, and $\mathrm{N}$ in agriculture, and it improves the nutrient availability because of an improved $\mathrm{pH}$ [116]. The application of aged manure from a dairy farm on an Alfisol Udalf increased the soil organic matter and soil exchangeable K content [117]. A greenhouse pot study of soybeans grown in acid soils amended with manure increased the $\mathrm{pH}$ compared with the control treatment (soil alone) [118]. The improved $\mathrm{pH}$ enhanced the uptake of $\mathrm{P}$ and $\mathrm{K}$, nodule formation, and productivity of soybeans. A manure application also increased exchangeable $\mathrm{K}$ and $\mathrm{Mg}$ [119]. A manure application is reported to increase the soil CEC and nutrient availability [120,121]. An increase in CEC was noted after a savanna Alfisol was cultivated continuously for 45 years when the soil was amended with manure compared with inorganic fertilisation [122]. In summary, manuring improves the $\mathrm{K}$ availability and uptake by altering the soil organic matter, CEC, and soil pH [123]. Nevertheless, it is essential to optimise the utilisation of manure to avoid the emission of greenhouse gases and volatile organic compounds; soil metal contaminations such as arsenic, copper, and zinc; and eutrophication, which is commonly caused by the leaching of N and P [124,125]. Qaswar et al. [126] cautioned that heavy metals in pig manure need to be adjusted before field applications to produce high crop yields with a minimum risk of heavy metal contamination in soil and food crops.

\subsection{Plant Residues}

The application of wheat and clover plant residue in an incubation study increased the soil $\mathrm{pH}$ within seven days because of the oxidation of organic anions [127]. Moreover, plant residues improve the soil structure and increase the soil carbon and water-holding capacity [128]. The improvement of the water-holding capacity enables the retention of potassium-rich water in soil, whereas an increased soil carbon provides additional exchange sites for $\mathrm{K}$ adsorption. This indicates that plant residues could increase the water-soluble $\mathrm{K}$ and exchangeable K retention. Properties such as the water infiltration and water-holding capacity were reported to increase with the incorporation of plants residues [129], and this directly relates to reducing leaching in tropical acid soils. Hence, the management of crop resides will improve the soil health and productivity. However, in some farming systems, crop residues are burnt, and this practice leads to greenhouse gas emissions [130]. Additionally, leaving crop residues on soil surfaces could influence ammonia volatilisation, whereas the incorporation could stimulate denitrification [131,132].

\subsection{Compost}

Compost is reputed for not only its ability to increase soil aggregate stability, porosity, carbon, and plant nutrients but reduces the $\mathrm{pH}$ and risk of erosion [133]. In an incubation study carried out by AyanfeOluwa et al. [134], amending Ultisol and Alfisol with conventional and accelerated composts increased the $\mathrm{pH}$, carbon, $\mathrm{N}, \mathrm{P}$, and $\mathrm{K}$ compared with a conventional practice (NPK fertilisation only). In a field study that was carried out to determine the benefits of the combined use compost and zeolite on the fertility of organic-rich Mediterranean soils, the available K concentration significantly increased compared with the control and zeolite only [135]. Although composts can improve the soil physical, chemical, and biological properties, there are some setbacks to it. For example, animal-based compost such as animal litter compost vary in their physicochemical proper- 
ties because of the different types of feeds animals consume [136]. On the other hand, the production and application of plant-based compost was reported to contaminate soils with heavy metals, salts, weed seeds, and pathogens [137]. Besides, during composting, C and $\mathrm{N}$ losses cause a decrease in the agronomic value of the compost and lead to greenhouse gases emission [138].

\subsection{Amending Acid Soils Using Organic Amendments to Improve the K Availability}

The application of organic amendments is one of the most promising options to improve the soil physicochemical properties. The improvement of the soil $\mathrm{pH}$, nutrient availability and uptake, and yield are some of the effects reported after the application of organic amendments (Table 1).

Table 1. Organic amendments application on the physicochemical properties of acid soils.

\begin{tabular}{|c|c|c|c|c|}
\hline Amendment & $\begin{array}{l}\text { Application } \\
\text { Rate }\end{array}$ & Soil Type & Impact on the K Availability & Reference \\
\hline Chicken manure & $15 \mathrm{tha}^{-1}$ & Typic Halpludox & 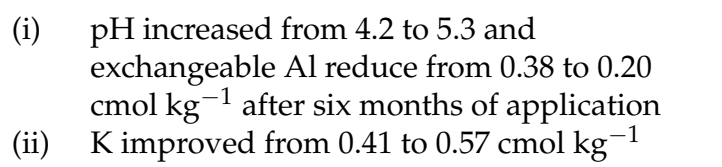 & $\begin{array}{l}\text { O'Hallorans et al. } \\
\text { [139] }\end{array}$ \\
\hline $\begin{array}{l}\text { Trifolium } \\
\text { alexandrinum L. } \\
\text { residue }\end{array}$ & Not stated & $\begin{array}{l}\text { Awagat series and } \\
\text { (loamy) Shahpur } \\
\text { series (silty) }\end{array}$ & $\begin{array}{l}\text { Higher and more immediate plant } \mathrm{K} \text { uptake in } \\
\text { coarse loamy soil compared to fine silty soil }\end{array}$ & $\begin{array}{l}\text { Rafique et al. } \\
\text { [140] }\end{array}$ \\
\hline Rice husk & $10 \mathrm{tha}^{-1}$ & Inceptisol & $\begin{array}{l}\text { pH improved from } 5.47 \text { to } 7.23 \text {, organic carbon } \\
\text { increased from } 0.43 \text { to } 14.48 \% \text {, and total } \mathrm{K} \\
\text { improved from } 0.42 \text { to } 0.47 \% \text { after rice pot trial }\end{array}$ & Roy et al. [141] \\
\hline $\begin{array}{l}\text { Coffee pulp and } \\
\text { husk }\end{array}$ & $\begin{array}{l}5,10, \text { and } \\
20 \mathrm{tha}^{-1}\end{array}$ & Arenosol & $\begin{array}{l}\text { Increased soil } \mathrm{pH} \text {, exchangeable } \mathrm{Ca}, \mathrm{Mg} \text {, and } \mathrm{K} \text { by } \\
5 \text { to } 7,2 \text { to } 3 \text {, and } 7 \text { to } 14 \text {-fold, respectively, whereas } \\
\text { reducing } \mathrm{Al} \text { toxicity }\end{array}$ & $\begin{array}{l}\text { Kasongo et al. } \\
\text { [142] }\end{array}$ \\
\hline $\begin{array}{l}\text { Citrus pulp } \\
\text { residues }\end{array}$ & $\begin{array}{l}30 \text { and } \\
90 \mathrm{tha}^{-1}\end{array}$ & Sandy loam & $\begin{array}{l}\text { Increase soil exchangeable } \mathrm{K} \text {, other cations, and soil } \\
\text { organic matter content }\end{array}$ & Meli et al. [143] \\
\hline $\begin{array}{l}\text { Rice straw } \\
\text { compost }\end{array}$ & $5 \mathrm{tha}^{-1}$ & Inceptisol & $\begin{array}{l}\text { Available } \mathrm{K} \text { for the amended treatment was } 257.2 \\
\mathrm{~kg} \mathrm{ha}^{-1} \text { compared with conventional practice was } \\
\qquad 230.9 \mathrm{~kg} \mathrm{ha}^{-1}\end{array}$ & $\begin{array}{l}\text { Meena and } \\
\text { Biswas [144] }\end{array}$ \\
\hline $\begin{array}{l}\text { Swine and cattle } \\
\text { manures }\end{array}$ & $\begin{array}{l}100,200 \\
\text { and } 400 \mathrm{~kg} \\
\text { total } \mathrm{N} \mathrm{ha}^{-1}\end{array}$ & Cudworth loam & $\begin{array}{c}\text { Repeated application of liquid swine and solid } \\
\text { cattle manure contributes to increases in extractable } \\
\text { soil K, and enhanced K concentration in plants } \\
\text { grown on the soils }\end{array}$ & Qian et al. [145] \\
\hline $\begin{array}{l}\text { City finished } \\
\text { compost }\end{array}$ & $\begin{array}{l}\text { 10, } 20 \text {, and } \\
40 \mathrm{tha}^{-1}\end{array}$ & Sandy loam & $\begin{array}{l}\text { (i) Radish dry weight were higher for treatments } \\
\text { added with compost }\left(10,20 \text {, and } 40 \mathrm{t} \mathrm{ha}^{-1}\right) \text { in } \\
\text { the absence of NPK fertilisation compared } \\
\text { with treatment with } 100 \% \text { recommended rate } \\
\text { of NPK } \\
\text { (ii) Treatment with } 40 \mathrm{tha}^{-1} \text { compost } \\
\text { demonstrated higher K uptake compared } \\
\text { with } 100 \% \text { recommended rate of NPK }\end{array}$ & Sarker et al. [146] \\
\hline Cattle manure & $40 \mathrm{~g} \mathrm{~kg}^{-1}$ & Silt loam & $\begin{array}{l}\text { (i) Increase available } \mathrm{K}, \mathrm{P} \text {, and Ca immediately } \\
\text { after application } \\
\text { (ii) Soils amended with } 40 \mathrm{~g} \mathrm{~kg}^{-1} \text { had three to } \\
\text { four times more plant available } \mathrm{P} \text { and } \mathrm{K} \text { than } \\
\text { unamended soils after } 8 \text { weeks of incubation }\end{array}$ & $\begin{array}{l}\text { Whalen et al. } \\
\text { [147] }\end{array}$ \\
\hline
\end{tabular}




\section{Humic Substances}

Humic substances are composed of heterogeneous and relatively small molecules that are produced through the breakdown of plant, animal, and microbial residues, which assemble themselves to form a supramolecular structure [148-150]. These smaller molecules consist of aromatic rings, aliphatic chains, and ionisable functional groups, which combine to generate complex colloids [151-153]. Stevenson [154] recorded that humic substance molecular weights range from a few hundred to millions of daltons. The structures of humic substances vary in relation to the $\mathrm{pH}$ and the type of metal present [155]. Previously, the formation of humic substances was known as the humification process. However, the 'humification' model itself has been abandoned, but the 'humic' nomenclature is maintained. For example, the large molecular size of 'humic substances' has been refuted but not their existence [152]. The issue has also been approached by redefining 'humic substances' as the portion of soil organic matter that cannot be molecularly characterised $[156,157]$ or by calling all soil organic matter 'humus' [158]. Humic substances are divided into three major fractions: namely, humic acids, fulvic acids, and humin. Humic substances are categorised into three distinctive fractions based on their solubility in water adjusted to different levels of $\mathrm{pH}$ : namely, humin, humic acid, and fulvic acid [154,159].

\subsection{Humic Acid}

Humic acids are dark brown to grey black in colour, comprising a mixture of weak aliphatic (carbon chains) and aromatic (carbon rings) organic acids that are not soluble in water under acidic conditions but are soluble in water under alkaline conditions $[160,161]$. Humic acids are precipitated from aqueous solution when the $\mathrm{pH}$ decreases below two. Due to their variable chemical features, they are termed colloidal polydispersed [162]. From a three-dimensional perspective, these complex carbon-containing compounds are known as flexible linear polymers that exist as random coils with crosslinked bonds. On average, $35 \%$ of humic acid molecules are aromatic, whereas the remaining components $(65 \%)$ are aliphatic molecules [163]. The molecular sizes of humic acids vary from 10,000 to 100,000 [164].

Various molecular structures describing the structure of humic acids have been proposed from the work of Stevenson [154] to more recent models of Schulten [165,166], Kujawinski et al. [167], and Stenson et al. [168,169]. A generally accepted structure for humic acids is one of the dynamic heterogeneous complexes of many different molecules at various stages of degradation that easily complex further with organic molecules, metal ions, or minerals $[154,170,171]$. Each of these complex compounds affects the solubility of humic acid differently, possibly because they bind different regions of the acid, form crosslinks between different acid molecules, or alter the exposed surface of the complex.

\subsection{Fulvic Acid}

Fulvic acids are a mixture of weak aliphatic and aromatic organic acids that are soluble in water under all pH conditions (acidic, neutral, and alkaline) [161]. After the removal of humic acids by acidification, fulvic acids remain in the solution [172]. Fulvic acids are light yellow to yellow brown [173], and they serve as a natural chelator of minerals and metals in soils. The size of fulvic acids is smaller than humic acids, with molecular weights ranging between 1000 and 10,000 [164]. Due to their relatively small-size molecules, they can easily enter plant roots, stems, and leaves. As they enter these plant parts, trace elements are transferred from plant surfaces to plant tissues. However, the oxygen content in fulvic acids is twice that of humic acids. They have many carboxyl and hydroxyl groups that make them more chemically reactive [174]. Additionally, the total acidity of the fulvic acids (900-1400 meq/100 g) is significantly higher than the humic acids (400-870 meq/100 g). Fulvic acids are also low in phenols and are less aromatic compared with humic acids from same source. 


\subsection{Humin}

Humin is the fraction of humic substances that is neither soluble in alkali (high $\mathrm{pH})$ nor in acid (low pH) and is black in colour $[161,175,176]$. The complexes of humin are considered macro-organic (very large) substances, because their molecular weights range from approximately 100,000 to 10,000,000 [164]. The chemical and physical properties of humin are only partially understood because of the extraction problems [177,178]. Among all the humic substances, humin is most resilient to decomposition in soils [175], as seen by the humin soil water-holding capacity, soil structure, fertility, soil stability, and CEC. The composition of humin is similar to those of the humic acids and fulvic acids. Humin may be a humic substance in association with mineral oxides or hydroxides [179]. Alternatively, humin may be coated with hydrocarbons or lipids (fats) that were stripped during the reaction, making them insoluble to aqueous solvents.

\subsection{Humates}

Mineral salts of humic acid and fulvic acid that are formed based on their ability to form negatively charged anions are known as humates [164]. Deprotonation of the functional groups of humic acid and fulvic acid results in the formation of negatively charged anions such as carboxyl and carbonyl. These negatively charged sites are able to bind cations such as $\mathrm{K}^{+}, \mathrm{Mg}^{2+}, \mathrm{Fe}^{2+}, \mathrm{Ca}^{2+}$, and $\mathrm{Mn}^{+}$[180]. Nevertheless, there is a significant variability in the molecular composition of different humic substances [181]. Humates from different mineral deposits have their own distinctive features.

\subsection{Variability of Chemical Structures in Humic Substances}

The elemental analysis of the humic substances demonstrates complex and variable structures [165]. The degradation of humic substances produces molecular components such as phenolic, carboxylic acids, $\mathrm{N}$-alkanes, and $\mathrm{N}$-fatty acids [182]. Most of the phenolic acids produced have approximately three hydroxyl group and approximately one to five carboxyl groups [183]. Table 2 summarises the functional groups of the humic substances.

Table 2. Chemical structures of the functional groups of the humic substances (adapted from Troeh and Thompson [67]).

\begin{tabular}{|c|c|c|}
\hline Functional Group & Chemical Structure & Explanation \\
\hline Carboxyl & & $\begin{array}{l}\text { The hydrogen could be ionized, thus creating a negatively charged } \\
\text { site that can attract cations. The single bond of the carbon in the } \\
\text { carboxyl group, ties it to an organic structure. }\end{array}$ \\
\hline Phenolic hydroxyl & & $\begin{array}{l}\text { The circle of carbon atoms creates a benzene ring, in which the fourth } \\
\text { bond of each of the carbon (in the benzene ring) can tie to another } \\
\text { part of an organic molecule, hydrogen atom or any other } \\
\text { atom/atoms. The H from the hydroxyl of this structure has a small } \\
\text { tendency to be ionised and creating a negatively charged site. }\end{array}$ \\
\hline Amine & & $\begin{array}{l}\text { Extra hydrogen may attach to the (two) free electrons of the } \mathrm{N} \text { in } \\
\text { amine resulting a positively charged site. Amine group can also react } \\
\text { with carboxyl group. Peptide bond can be formed with the removal a } \\
\text { water molecule. Peptide bond links amino acids to form proteins. }\end{array}$ \\
\hline
\end{tabular}

\subsection{Functions of Humic Substances}

Humic substances contribute to the structure of the soil, water retention, diversification, activity of soil biota, and nutrient availability (ion exchange capacity). Carbon bonds in humic substances supply energy for various beneficial soil organisms that lack photosynthetic capabilities [184]. These organisms rely on the residual carbon to carry out metabolic reactions. In turn, the beneficial soil organisms contribute by making the soil richer through different metabolic functions [185]. Moreover, the large surface area and internal electric charges of humic substances increases the water-holding capacity of the soil. Presence of 
humic substances make the soil structure to be more convenient for water infiltration and water retention, especially in the root areas. Bot and Benites [186] affirmed that humic substances are able to retain water seven times more than their volume, which is, in fact, higher than soil clays. Furthermore, the ability to buffer $\mathrm{H}^{+}$concentration in soils enables humic substances to neutralise the changes in $\mathrm{pH}$ in addition to liberating $\mathrm{CO}_{2}$ [164]. This feature prevents nutrient unavailability because of soil acidity or alkalinity. The liberation of $\mathrm{CO}_{2}$ from $\mathrm{Ca}$ carbonates in the soil by humic substances can be taken up by plants or form carbonic acids that act on soil minerals to release plant nutrients. Additionally, humic acids and fulvic acids are involved in the chelation and sorption of cations. Chelation is the termed coined when a cation (with the exception of monovalent cations) enters a part of the molecule where the positive charge of the cation pulls negatively charged groups towards it like a self-entrapment [187]. As a result, the toxicity of $\mathrm{Al}^{3+}$ and $\mathrm{Fe}^{2+}$ are reduced with the presence of humic substances. The high negative charge density of humic substances prevents the leaching of important cations such as $\mathrm{K}^{+}$by increasing their sorption capacity in soils [188].

\section{Charcoal and Its Properties}

Charcoal is the product derived from the thermal degradation in absent or low oxygen atmosphere (pyrolysis) of lignocellulosic residues from either forestry (sawdust, woodchips, and bark) or agriculture (corn stalks, coconut, rice husks, and manure) [189]. These aromatic structures are stable and are responsible for the recalcitrance of charcoal [190]. Charcoal has high adsorptive capacity because of carbonisation [191,192]. Charcoal has a high initial carbon density (70-85\%) relative to a typical woody biomass $(<50 \%)$, and it is primarily made up of irregularly arranged aromatic rings, with a highly porous structure $[193,194]$. The proportion of aromatic carbon in charcoal increases with the increasing temperature because of an increased loss of volatile matter and the conversion of alkyl groups to aryl groups [195]. The loss of volatile matter creates voids that form an extensive pore network in the charcoal's structure [191].

\subsection{Amending Soil with Charcoal}

Charcoal has recently been heralded for its ability to increase plant productivity and ameliorate poor soil conditions across a variety of systems while mitigating anthropogenic climate change by enhancing soil carbon sequestration [196]. Charcoal's ability in enhancing plant growth is attributed to an increased soil $\mathrm{pH}$ and the sorption of growth-inhibitory compounds [197]. In addition, the presence of a highly porous aromatic structure provides charcoal with the ability to hold cations $[198,199]$. The negative charge density of charcoal increases the CEC of soil, hence increasing the adsorption of cations and P. [108,200]. The enhancement of soil CEC showed that adding charcoal is not only a soil conditioner but also capable of acting as a fertiliser [201-203]. Table 3 demonstrates the other effects of charcoal application on acid soils.

Table 3. Charcoal application on the nutrient availability in acid soils.

\begin{tabular}{cc}
\hline \multicolumn{1}{c}{ Effect of Charcoal on Nutrient Availability } & References \\
\hline $\begin{array}{c}\mathrm{NH}_{4}+\text { availability reduced and 35\% increase in available } \mathrm{K} \text { in } \\
\text { flooded or anaerobic soil }\end{array}$ & Barbosa de Sousa et al. [204] \\
\hline $\begin{array}{c}\mathrm{C} \text { and exchangeable } \mathrm{K} \text { contents increase, } \mathrm{NH}^{+} \text {was retained } \\
\text { in the soil, and Al contents reduced }\end{array}$ & Lehmann et al. [205] \\
\hline $\begin{array}{c}\text { Improvement in the pH, } \mathrm{K} \text { availability, and CEC, whereas } \mathrm{Ca} \\
\text { and } \mathrm{Mg} \text { decreased }\end{array}$ & Major et al. [197] \\
\hline $\begin{array}{c}\text { Although } \mathrm{Na}, \mathrm{Cu}, \mathrm{Ni} \text { and Cd uptake by plant decreased, } \mathrm{K}, \\
\mathrm{Mg} \text {, and Zn increased }\end{array}$ & Glaser et al. [206] \\
\hline
\end{tabular}




\subsection{Potential Risks of Using Charcoal as Soil Amendments}

Nevertheless, there is increasing evidence that charcoal does not always have favourable effects on soil and soil biota. Excessive doses of charcoal (for example, $30 \mathrm{mg} \mathrm{kg}^{-1}$ ) added to clay soils could cause water insufficiency in agricultural soils, thus reducing yields [207]. Charcoal application also hampers the soil formation rate because of its recalcitrance and charcoal alone application is likely to outstrip the natural soil formation rate $[208,209]$. Due to its porosity and large specific surface area, the use of charcoal could reduce the efficacy of such agrochemicals [210]. An increased charcoal absorption capacity reduces the fraction of agrochemicals bioavailable to microbial degraders; thus, a higher dose of pesticide or herbicide is required [211-214]. Moreover, charcoal could be a source of organic contaminants, including polycyclic aromatic hydrocarbons (PAHs), volatile organic compounds (VOCs), potentially toxic elements (PTEs), and dioxins. Therefore, it is essential to evaluate charcoal's long-term effects before it is used as a soil amendment to minimise the adverse effects on both the environment and human health.

\section{Wood Ash and Its Properties}

Wood ash is the inorganic and organic residue remaining after the combustion of wood or unbleached wood fibre [17]. Organic compounds are mineralised, whereas the base cations form oxides that are slowly hydrated and carbonated under atmospheric conditions [17]. However, carbon and nitrogen are usually in negligible amounts, if not absent, because both elements are oxidised and transformed into gas during combustion. The physical and chemical properties of wood ash vary significantly, depending on several factors. The key determinants of wood ash chemistry are the tree species combusted, the nature of the burn process, and the conditions at the application site $[215,216]$. The particle size of most ash is less than $1.0 \mathrm{~mm}$ [217], and the bulk density is approximately $0.27 \mathrm{~g} \mathrm{~cm}^{-3}[218]$.

\subsection{Amending Soil with Wood Ash}

Wood ash has a small particle size, and this enables a faster $\mathrm{pH}$ alteration period compared with commercial lime. Furthermore, wood ash provides a considerable amount of plant nutrients such as $\mathrm{P}, \mathrm{Ca}, \mathrm{K}$, and $\mathrm{Mg}[19,219-223]$. Despite the ability to increase the major cations and anions in a soil solution, wood ash does not prevent nutrient loss through leaching losses [222,223]. Wood ash does not only substitute lime or provide macronutrients; it can also offer a substantial amount of sulphur, boron, and other micronutrients. Wood ash is being used in farms after its potential to substitute commercial lime was made known [224]. The smaller particle size makes wood ash superior in terms of time taken to improve the $\mathrm{pH}$ [217]. Additionally, wood ash is a good source of $\mathrm{K}, \mathrm{P}$, and $\mathrm{Mg}$ [225]. The oxides and carbonates of $\mathrm{Ca}$ and $\mathrm{K}$ of wood ash make it alkaline [226,227]. The nutrient composition depends on the tree species used, whether it originates from bark or wood and the combustion process efficiency. It also can replace the macro- and micronutrients removed during plant growth and harvesting. Wood ash is more soluble and reactive than ground limestone [228] and brings about a change in soil pH more rapidly than lime [229,230]. Lime can take six months to one year to fully take effect. Wood ash is a good source $\mathrm{K}$ (5\%), Ca (25\%), P (2\%), and $\mathrm{Mg}(1 \%)$, which are essential plant nutrients $[220,231,232]$. Crops positively respond to $\mathrm{K}$ and $\mathrm{P}$ from wood ash. Other micronutrients in wood ash include boron, copper, molybdenum, sulphur, and zinc [233]. Each ton of wood ash can substitute up to one ton of agricultural lime and could supply 25-70 pounds of potash $\left(\mathrm{K}_{2} \mathrm{O}\right)$ and 30-32 pounds of phosphate $\left(\mathrm{P}_{2} \mathrm{O}_{5}\right)$ [224]. Chang et al. [234] found an increased water conductivity of soil at with ash amendments. Table 4 demonstrates the effects of wood ash application on the $\mathrm{K}$ availability in acid soils. 
Table 4. Wood ash application on the potassium availability in acid soils.

\begin{tabular}{cc}
\hline Effects of Ash on the K Availability and Soil Properties & Reference \\
\hline $\begin{array}{c}\text { The } \mathrm{K} \text { content in the soil of the sample plots one year after the application of wood ash increased two } \\
\text { to six times in comparison to the control plots, depending on wood ash concentration. }\end{array}$ & Jansone et al. [235] \\
proportionally with ash application rates. & Sharifi et al. [236] \\
\hline $\begin{array}{c}\text { Wood ash treatments enhanced uptake of } \mathrm{K}^{+} \text {compared with the control. Potassium uptake increased } \\
\text { Application of plant derived ash increased the availability of } \mathrm{K} \text { and } \mathrm{Mg} \text { in soil and } \mathrm{K} \text { content in plant } \\
\text { tissue. Application of ash at } 1500 \mathrm{mg} \mathrm{K}_{2} \mathrm{O} \text { improved soil pH to } 7.4 \text { within two months after } \\
\text { application but reduced afterwards. }\end{array}$ & Baon et al. [237] \\
\hline $\begin{array}{c}\text { After the application of wood ash, the } \mathrm{P}_{2} \mathrm{O}_{5} \text { and } \mathrm{K}_{2} \mathrm{O} \text { content of the soil rose significantly. The } \\
\text { treatments also increased the } \mathrm{Mg}, \mathrm{S} \text {, and } \mathrm{Zn} \text { content in the soil. }\end{array}$ & Füzesi et al. [238] \\
\hline
\end{tabular}

\subsection{Potential Risks of Using Wood Ash as Soil Amendment}

The long-term application of wood ash to soil could increase the soil salinisation. Soil salinity increases through the release of both ash water-soluble and water-insoluble salts into the soil solution. Increased salt concentration is a major environmental problem affecting crop production worldwide, because approximately $20 \%$ of cultivated land is currently salt-affected and degraded $[239,240]$. Additionally, excessively raised soil pH following the application of wood ash results in the unavailability of important plant nutrients. For example, at alkaline $\mathrm{pH}, \mathrm{P}$ precipitates with $\mathrm{Ca}$ to form calcium phosphate, which is unavailable for plant uptake [67]. Thus, there is a need to determine the $\mathrm{pH}$ of the specific ash before its application to susceptible soil types. Another concern of ash application in agriculture is the presence of heavy metals. Ash contains several potentially toxic elements, such as $\mathrm{As}, \mathrm{Cu}, \mathrm{Zn}, \mathrm{Cd}, \mathrm{Pb}, \mathrm{Co}, \mathrm{Mo}, \mathrm{Mn}, \mathrm{Hg}, \mathrm{Ni}, \mathrm{Cr}$, Se, and B [241]. These heavy metals can be leached from soils and can lead to the pollution of land and water bodies. The studies by Ram and Masto [242], Singh et al. [243], and Ferreira et al. [244] reported that $5-30 \%$ of heavy metals in ash are leachable.

\section{Prospects of Co-Applying Charcoal and Wood Ash as Soil Amendments}

Charcoal and ash have different mechanisms that benefit soil fertility. The ability of charcoal to improve soil fertility revolves within three main mechanisms: (i) a direct modification of soil chemistry through its inherent elements and composition, (ii) exchange sites that regulate the soil nutrients dynamics, and (iii) the improvement of soil physical characteristics in a way that promotes root growth, nutrient uptake, and water retention [245]. On the other hand, wood ash is mainly associated with the physicochemical improvements of soil because of its high alkalinity. The oxides from ash could activate the functional groups of charcoal to provide synergistic benefits, such as enhanced nutrient availability, pH buffering capacity, and decrease bioavailability of heavy metals [246].

Several literatures have the outlined effects of applying charcoal and ash on acid soils (alone and combined application). Separate applications of ash and charcoal significantly reduced $\mathrm{Al}^{3+}$ concentration compared with control treatment [247,248]. The addition of ash demonstrated largest increased in available $\mathrm{K}$ concentration compared with charcoal and commercial lime. After the first planting season, soil amended with ash had $1.68 \mathrm{cmol} \mathrm{kg}^{-1} \mathrm{~K}$, whereas soil amended with charcoal and lime contained 0.49 and $0.04 \mathrm{cmol} \mathrm{kg}^{-1} \mathrm{~K}$, respectively [247]. This is caused by the nutrient addition effects of ash. The ashing process burns organic portion of biomass materials, resulting in a product that is enriched with nutrients such as $\mathrm{K}, \mathrm{Ca}$, and $\mathrm{Mg}$ [243]. Bieser and Thomas [249] reported a higher metal availability in soils amended with wood ash compared with charcoal. This is mainly attributed to the ability of charcoal to precipitate the heavy metals. Hale et al. [247] revealed that the average maize yield increased by seven-fold for biochar and eight-fold for ash and are greater than commercial lime, which increased the yield by five-fold compared with the control. Although information on the co-application of charcoal and wood ash is limited, some studies used fly ash as an alternative to wood ash. Masto et al. [250] 
reported that the $\mathrm{pH}$ of charcoal and fly ash treated soils increased from 6.09 to 6.64 and 6.58 , respectively. A combined application of charcoal and fly ash further increased the soil $\mathrm{pH}$ to 6.69. The addition of organic amendments along with ash was reported to result in an additional $\mathrm{pH}$ buffering capacity because of the $\mathrm{Ca}^{2+}$ present in ash [242]. Nevertheless, fly ash alone only increased the $\mathrm{K}$ content in soil at the vegetative state. Charcoal alone and a co-application with fly ash treatments increased the soil available $\mathrm{K}$ at all crop stages (vegetative, tasselling, and grain filling). Charcoal was reported to sorb significant amounts of heavy metals because of the structured carbon matrix of charcoal with a high degree of porosity and extensive surface area [251,252]. The increase in soil pH by ash promotes charcoal's ability to form complexes with heavy metals [250].

\section{Mechanisms behind Using Charcoal and Wood Ash to Increase Potassium Availability}

The co-application of charcoal and wood ash has the potential to improve the $\mathrm{K}$ availability through several mechanisms. The alkaline nature of both amendments increases soil $\mathrm{pH}$. In addition, further decomposition of charcoal releases organic compounds [16], which could chelate $\mathrm{Al}^{3+}$ and $\mathrm{Fe}^{2+}$ to stop these ions from hydrolysing to release hydrogens, which have been implicated in causing soil acidity. The high surface area and porous structure of charcoal could reduce mobility of water-soluble $\mathrm{K}$ by trapping nutrient-rich water. Furthermore, charcoal and wood ash co-application could increase the K sorption capacity of tropical acid soils by providing exchanges sites for $\mathrm{K}$ and reducing leaching.

\subsection{Increasing Potassium Sorption Capacity}

The adsorption capacity of soil is an important property that regulates leaching and redistribution of both anions and cations [253]. To temporarily hold nutrients before being taken up by plants, high CEC of soil amendments can be exploited [6]. The CEC is one of the most important indicators for evaluating soil fertility more specifically for nutrient. For example, exchangeable base cations and ECEC (effective cation exchange capacity) can be increased using ash [254]. Besides, surface oxidation of aromatic rings of charcoal causes carboxylation which results in creating large numbers of negative-charged sites [255]. Negative surface charges of charcoal increase soil CEC causing adsorption of cations and P to increase, whereas nutrient leaching is reduced. Moreover, application of charcoal in soils increases humic and fulvic acids which have numerous functional groups such as R-COO-, $\mathrm{R}-\mathrm{C}=\mathrm{O}, \mathrm{R}-\mathrm{COH}, \mathrm{R}-\mathrm{SH}$, and others. These functional groups have the ability to adsorb or chelate cations to improve their future availability [256-258]. Addition of charcoal improves $\mathrm{K}^{+}$retention by reducing its mobility in soil [155]. Eventually, the likelihood of $\mathrm{K}$ being held onto the soil colloids can be increased and leaching could be reduced significantly (Figure 4). Since leaching and plant uptake will deplete water-soluble K, it is essential to maintain the exchangeable $\mathrm{K}$, where this pool can be activated to replenish the $\mathrm{K}$ in soil solution. At the same time, $\mathrm{pH}$ of the soil has to be raised to deprotonate the functional groups of charcoal and make the basic cations such as $\mathrm{K}$ to be more reactive and available for plants.

\subsection{Retention of Water to Reduce Mobility of Potassium in Soil}

The particle size, structure, and organic matter contents of amendments influence the soil water holding capacity $[259,260]$. Charcoal is known for its high surface area because of its porosity. Charcoal pore size ranges between sub-nanometres and tens of micrometres [261,262]. The pores are classified into macro-pores, meso-pores, and nanopores depending on their internal diameter $[263,264]$. Macro-pores are sized greater than $50 \mathrm{~nm}$ and they make up approximately 95\% of charcoal's total porosity [265]. Macro-pores facilitate microbial activity and water retention. On the other hand, meso-pores and micropores are known charcoal's active site where nutrient retention occurs, and they are sized 2-50 $\mathrm{nm}$ and less than $2 \mathrm{~nm}$ [191]. Meso-pores and micro-pores contribute approximately $5 \%$ of charcoal's total porosity. Tryon [266] reported increase in soil water holding capacity by $18 \%$ with the application of $45 \%$ charcoal to a sandy soil. Glaser et al. [202] asserted 
that the large internal surface area of charcoal and the high number of residual pores are the reasons behind charcoal's ability to retain water. Since polyaromatic backbones are hydrophobic in nature, they increase the water availability by limiting the water backflow into the pores [155]. Eliche-Quesada et al. [267] characterized rice husk ash and wood ash using scanning electron microscopy and energy dispersive X-ray spectrometry (SEM/EDX) and it demonstrated the highly porous structure and small particle size of both types of ash. Two other preceding studies have detected improved soil water retention and hydraulic conductivity via the application of soil amendments with high surface area and porosity $[268,269]$. Increase in water holding capacity enhances uptake of nutrient because the uptake is mediated by soil solution [270]. This creates an environment where leaching of $\mathrm{K}$ is minimized by regulating water loss from the soil profile. Hence, making $\mathrm{K}^{+}$available in the soil solution for plants to uptake and expend.

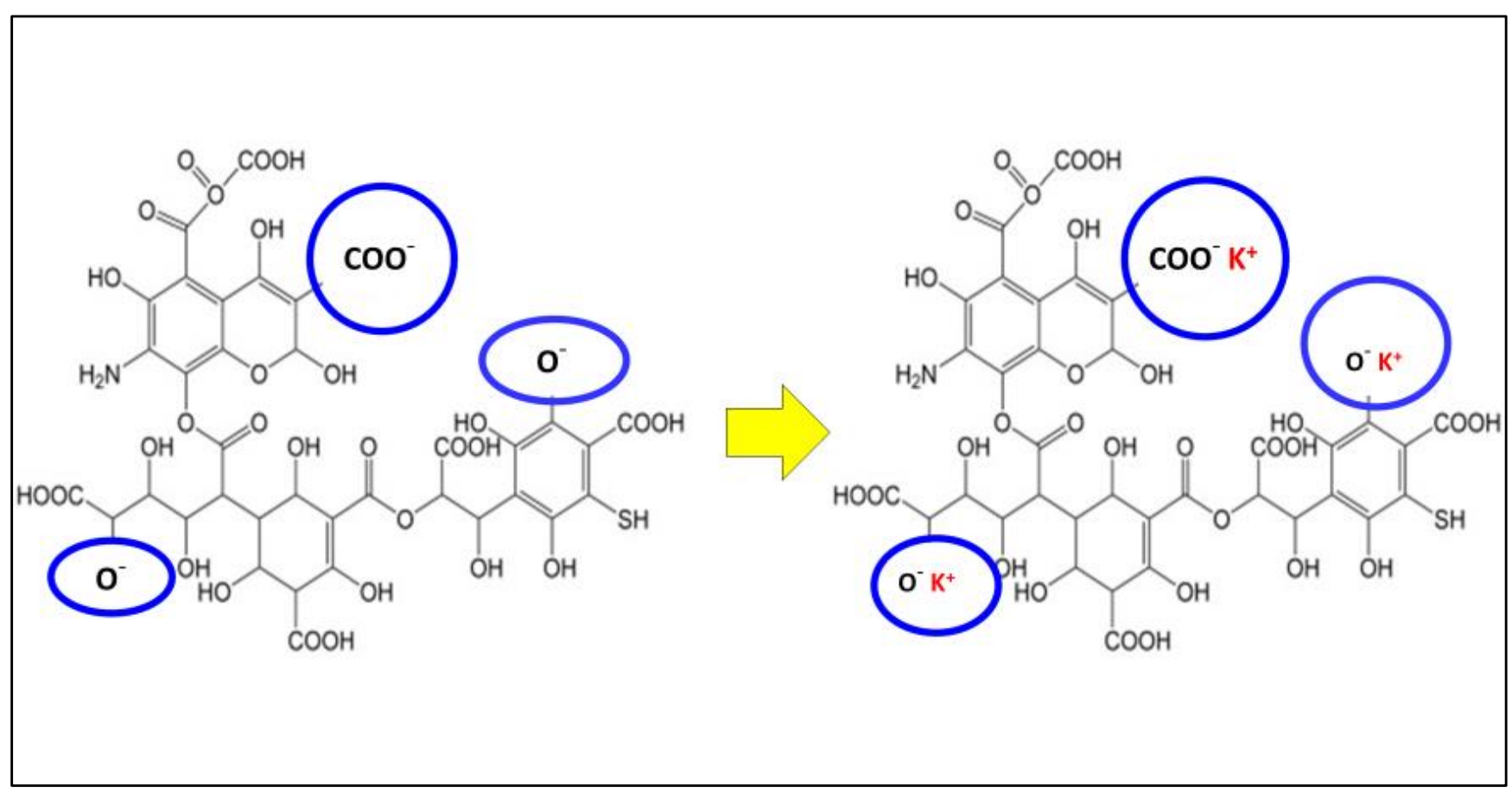

Figure 4. Proposed mechanism of potassium retention at the negatively charged exchange sites of organic amendments (adapted from Troeh and Thompson [64]).

\subsection{Improvement Soil pH upon Application of Charcoal and Wood Ash}

Most ash $\mathrm{pH}$ range between 8.9 and 13.5 [17]. It was also reported that application of wood ash can reduce soil acidity, as well as $\mathrm{Al}^{3+}$ and $\mathrm{Fe}^{2+}$ toxicity $[18,19]$. Previous studies on ash from different sources indicated its potential as soil amendment [271-273]. Calcite, lime and $\mathrm{Mg}$ oxides in ash neutralise the soil acidity [187]. It could also break the bonds of functional groups through the effect of $\mathrm{Ca}$ and $\mathrm{Mg}$ [176]. The utilisation of charcoal as soil amendment showed nascent feedbacks as it provides reactive negatively charged surfaces that can assist in nutrient holding or chelation of detrimental cations $\left(\mathrm{Al}^{3+}\right.$ and $\left.\mathrm{Fe}^{2+}\right)$ [274] Upon its application, charcoal decomposes in soils to produce organic compounds which have affinity for $\mathrm{Al}^{3+}$ and $\mathrm{Fe}^{2+}$ (Figure 5). As the $\mathrm{pH}$ increases, not only is $\mathrm{K}^{+}$adsorbed into the exchange sites (due to deprotonation of functional groups), it is more reactive, hence easing the uptake by plants. 


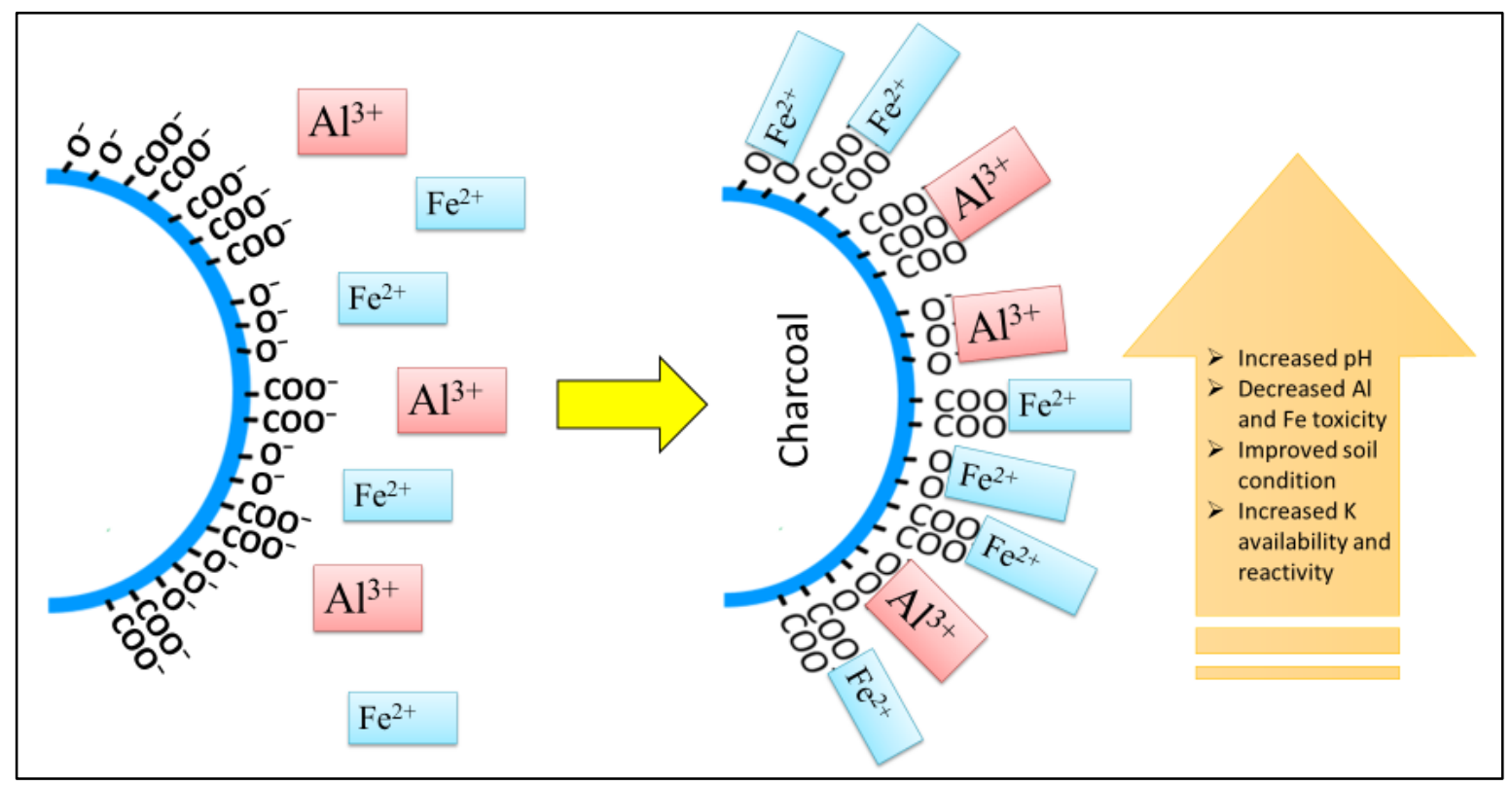

Figure 5. Proposed mechanism of aluminium and iron chelation reactions at the negatively charged exchange sites of soil amendments (adapted from Brady and Weil [31]).

\section{Future Perspectives and Recommendations}

To date, the co-application of charcoal and wood ash to improve the K availability in tropical acid soils is scarcely explored. It is important to continue and extend research concerning the effect of co-application of charcoal and wood ash as soil amendments. Firstly, research should be carried out on the long-term impact of these amendments on soil properties, microbial activity and diversity, and crops quality. Furthermore, the fate of toxic compounds in these amendments (including heavy metals and radionuclides) should be carefully investigated. Additionally, potential contaminants leaching from soil enriched with charcoal and wood ash and their impact on the surrounding environment should be continuously monitored. Moreover, there are limited information on the optimal use of these amendments. To address the research gap on using charcoal and wood ash on the K availability, there is a need to carry out laboratory and field trials to verify the proposed mechanisms. The optimal rates of charcoal and wood ash to improve the K availability can be obtained through such studies. Plant response towards co-application of these amendments could be identified to avoid exceeding the toxic threshold.

\section{Conclusions}

The availability of soil $\mathrm{K}$ requires systemic evaluation because of its association with $\mathrm{K}$ fractions in soil. The chemical and physical processes and the retention-release mechanisms regulating the $\mathrm{K}$ availability in the soil need to be studied. The suppression of $\mathrm{Al}$ and $\mathrm{Fe}$ toxicity in tropical acid soils needs to be evaluated to increase $\mathrm{K}$ reactivity. At the same time, decreasing $\mathrm{K}$ mobility in soil solution by providing exchange sites for $\mathrm{K}$ to be adsorbed requires thorough understanding. The co-application of soil amendments, particularly charcoal and wood ash is believed to not only decrease K leaching but also improve the $\mathrm{K}$ availability and use efficiency in acid soils. This could be accomplished by the large numbers of negative-charged sites in organic substances of charcoal that not only alter K sorption capacity in soils but chelate the $\mathrm{Al}$ and Fe oxides. On the other hand, application of wood ash can be regarded as substitute for commercial lime because of the presence of acid neutralising compounds that could inhibit $\mathrm{Al}$ and Fe hydrolysis and deprotonate the functional groups in charcoal's organic substances. Extended research is required to study the effects of charcoal and wood ash application towards soil, crop, and environment to achieve sustainable agriculture. 
Author Contributions: Conceptualisation, P.P. and P.D.J.; resources, O.H.A., L.O. and H.Y.C.; writing—original draft preparation, P.P.; writing—review and editing, P.P., O.H.A. and P.D.J.; visualisation, P.P. and N.H.H.; supervision, O.H.A.; L.O. and H.Y.C.; and funding acquisition, O.H.A. All authors have read and agreed to the published version of the manuscript.

Funding: This research was funded by the Ministry of Higher Education, Malaysia with grant number ERGS/1/11/STWN/UPM/02/65.

Institutional Review Board Statement: Not applicable.

Informed Consent Statement: Not applicable.

Data Availability Statement: This study did not report any data.

Acknowledgments: The authors acknowledge the support of the Ministry of Higher Education, Malaysia and Universiti Putra Malaysia for this paper.

Conflicts of Interest: The authors declare no conflict of interest.

\section{References}

1. Okalebo, J.R.; Othieno, C.O.; Nekesa, A.O.; Ndungu-Magiroi, K.W.; Kifuko-Koech, M.N. Potential for agricultural lime on improved soil health and agricultural production in Kenya. Afr. Crop. Sci. Conf. Proc. 2009, 9, 339-341.

2. Fageria, N.K.; Slaton, N.A.; Baligar, V.C. Nutrient Management for Improving Lowland Rice Productivity and Sustainability. Adv. Agron. 2003, 80, 63-152.

3. Usharani, K.V.; Roopashree, K.M.; Naik, D. Role of soil physical, chemical and biological properties for soil health improvement and sustainable agriculture. J. Pharmacogn. Phytochem. 2019, 8, 1256-1267.

4. Gunamantha, I.M.; Sudiana, I.K.; Sastrawidana, D.K.; Suryaputra, I.N.G.A.; Oviantari, M.V. The evaluation of soil fertility status of open space in campus area and their suitability for tropical fruits production. J. Soil Sci. Environ. Manag. 2021, 12, 78-85. [CrossRef]

5. Obalum, S.E.; Chibuike, G.U.; Peth, S.; Ouyang, Y. Soil organic matter as sole indicator of soil degradation. Environ. Monit. Assess. 2017, 189, 176. [CrossRef]

6. Latifah, O.M.A.R.; Ahmed, O.H.; Majid, N.A. Enhancing nutrients use efficiency and grain yield of Zea mays L. cultivated on a tropical acid soil using paddy husk compost and clinoptilolite zeolite. Bulg. J. Agric. Sci. 2017, 23, 418-428.

7. Uzoma, K.C.; Inoue, M.; Andry, H.; Fujimaki, H.; Zahoor, A.; Nishihara, E. Effect of cow manure biochar on maize productivity under sandy soil condition. Soil Use Manag. 2011, 27, 205-212. [CrossRef]

8. Chaparro, J.M.; Sheflin, A.M.; Manter, D.K.; Vivanco, J.M. Manipulating the soil microbiome to increase soil health and plant fertility. Biol. Fertil. Soils 2012, 48, 489-499. [CrossRef]

9. Maru, A.; Haruna, A.O.; Asap, A.; Majid, N.M.A.; Maikol, N.; Jeffary, A.V. Reducing Acidity of Tropical Acid Soil to Improve Phosphorus Availability and Zea mays L. Productivity through Efficient Use of Chicken Litter Biochar and Triple Superphosphate. Appl. Sci. 2020, 10, 2127. [CrossRef]

10. Audrey, A.; Haruna, A.O.; Majid, N.M.A.; Maru, A. Amending triple superphosphate with chicken litter biochar improves phosphorus availability. Eurasian J. Soil Sci. 2018, 7, 121-132.

11. Liu, Z.; Rong, Q.; Zhou, W.; Liang, G. Effects of inorganic and organic amendment on soil chemical properties, enzyme activities, microbial community and soil quality in yellow clayey soil. PLoS ONE 2017, 12, e0172767. [CrossRef]

12. Zaki, M.K.; Komariah, K.; Rahmat, A.; Pujiasmanto, B. Organic amendment and fertilizer effect on soil chemical properties and yield of maize (Zea mays L.) in rainfed condition. Walailak J. Sci. Technol. 2020, 17, 11-17. [CrossRef]

13. Penido, E.S.; Martins, G.C.; Mendes, T.B.M.; Melo, L.C.A.; do Rosário Guimarães, I.; Guilherme, L.R.G. Combining biochar and sewage sludge for immobilization of heavy metals in mining soils. Ecotoxicol. Environ. Saf. 2019, 172, 326-333. [CrossRef]

14. Carrier, M.; Hardie, A.G.; Uras, Ü.; Görgens, J.; Knoetze, J.H. Production of char from vacuum pyrolysis of South-African sugar cane bagasse and its characterization as activated carbon and biochar. J. Anal. Appl. Pyrolysis 2012, 96, 24-32. [CrossRef]

15. Choi, S.K.; Yum, K.W.; Chon, S.U. Effect of Activated Charcoal on Growth of Curcuma longa Linne. Plant Resour. 2003,6 , $175-177$.

16. Yu, X.Y.; Ying, G.G.; Kookana, R.S. Sorption and desorption behaviors of diuron in soils amended with charcoal. J. Agric. Food Chem. 2006, 54, 8545-8550. [CrossRef]

17. Demeyer, A.; Nkana, J.V.; Verloo, M.G. Characteristics of wood ash and influence on soil properties and nutrient uptake: An overview. Bioresour. Technol. 2001, 77, 287-295. [CrossRef]

18. Mandre, M.; Pärn, H.; Ots, K. Short-term effects of wood ash on the soil and the lignin concentration and growth of Pinus sylvestris L. For. Ecol. Manag. 2006, 223, 349-357. [CrossRef]

19. Ohno, T. Neutralization of soil acidity and release of phosphorus and potassium by wood ash. J. Environ. Qual. 1992, 21, 433-438. [CrossRef]

20. Eyre, S.R. Vegetation and Soils: A World Picture; Routledge: Abingdon, UK, 2017.

21. McGivney, E.; Gustafsson, J.P.; Belyazid, S.; Zetterberg, T.; Löfgren, S. Assessing the impact of acid rain and forest harvest intensity with the HD-MINTEQ model-soil chemistry of three Swedish conifer sites from 1880 to 2080. Soil 2019, 5, 63-77. [CrossRef] 
22. Berger, T.W.; Türtscher, S.; Berger, P.; Lindebner, L. A slight recovery of soils from Acid Rain over the last three decades is not reflected in the macro nutrition of beech (Fagus sylvatica) at 97 forest stands of the Vienna Woods. Environ. Pollut. 2016, 216, 624-635. [CrossRef] [PubMed]

23. Sadri, F.; Nazari, A.M.; Ghahreman, A. A review on the cracking, baking and leaching processes of rare earth element concentrates. J. Rare Earths 2017, 35, 739-752. [CrossRef]

24. Goulding, K.W.T. Soil acidification and the importance of liming agricultural soils with particular reference to the United Kingdom. Soil Use Manag. 2016, 32, 390-399. [CrossRef]

25. Evangelou, V.P. Pyrite Oxidation and Its Control; CRC Press: London, UK, 2018.

26. Jones, D.L.; Dennis, P.G.; Owen, A.G.; Van Hees, P.A.W. Organic acid behavior in soils-misconceptions and knowledge gaps. Plant Soil 2003, 248, 31-41. [CrossRef]

27. Kumari, A.; Kapoor, K.K.; Kundu, B.S.; Kumari Mehta, R. Identification of organic acids produced during rice straw decomposition and their role in rock phosphate solubilization. Plant Soil Environ. 2008, 54, 72. [CrossRef]

28. Valentine, A.J.; Benedito, V.A.; Kang, Y. Legume nitrogen fixation and soil abiotic stress: From physiology to genomics and beyond. Annu. Plant Rev. Online 2018, 2018, 207-248.

29. Sumner, M.E.; Noble, A.D. Soil acidification: The world story. In Handbook of Soil Acidity; Marcel Dekker: New York, NY, USA, 2003.

30. Duarte, I.M.; Gomes, C.S.; Pinho, A.B. Chemical Weathering. Encycl. Eng. Geol. 2018, 2018, 114-120.

31. Brady, N.C.; Weil, R.R. The Nature and Properties of Soils; Prentice Hall: Upper Saddle River, NJ, USA, 2008 ; pp. 662-710.

32. Gazey, C. Effects of Soil Acidity; Agriculture and Food Department of Primary Industries and Regional Development Government of Western Australia. 2018. Available online: https://www.agric.wa.gov.au/soil-acidity/effects-soil-acidity?page=0\%2C1 (accessed on 22 April 2021).

33. Palanivell, P. Organic and Mineral Amendments on Rice (Oryza sativa L.) Yield and Nutrients Recovery Efficiency. Ph.D. Thesis, Universiti Putra Malaysia, Seri Kembangan, Malaysia, 2016.

34. Jusop, S.; Ishak, C.F. Weathered Tropical Soils: The Ultisols and Oxisols; UPM Press: Serdang, Malaysia, 2010.

35. Shamshuddin, J.; Daud, N.W. Classification and management of highly weathered soils in Malaysia for production of plantation crops. In Principles, Application and Assessment in Soil Science; IntechOpen: London, UK, 2011; pp. 75-86.

36. Uehara, G.; Gillman, G. The Mineralogy, Chemistry, and Physics of Tropical Soils with Variable Charge Clays; Westview Press: Boulder, CO, USA, 1981.

37. Al-Ani, T.; Sarapää, O. Clay and clay mineralogy. In Physical-Chemical Properties and Industrial Uses; GTK: Espoo, Finland, 2008.

38. Chorover, J.; Sposito, G. Surface charge characteristics of kaolinitic tropical soils. Geochim. Cosmochim. Acta 1995, 59, 875-884. [CrossRef]

39. Ma, C.; Eggleton, R.A. Cation exchange capacity of kaolinite. Clays Clay Miner. 1999, 47, 174-180.

40. Wattel-Koekkoek, E.J.W.; Van Genuchten, P.P.L.; Buurman, P.; Van Lagen, B. Amount and composition of clay-associated soil organic matter in a range of kaolinitic and smectitic soils. Geoderma 2001, 99, 27-49. [CrossRef]

41. Lal, R.; Hall, G.F.; Miller, F.P. Soil degradation: I. Basic processes. Land Degrad. Dev. 1989, 1, 51-69. [CrossRef]

42. Melo, V.F.; Singh, B.; Schaefer, C.E.G.R.; Novais, R.F.; Fontes, M.P.F. Chemical and mineralogical properties of kaolinite-rich Brazilian soils. Soil Sci. Soc. Am. J. 2001, 65, 1324-1333. [CrossRef]

43. Patil, S.; Kumar, K.A. Characterization and classification of soils of west coast of southern Karnataka. J. Indian Soc. Soil Sci. 2014, $62,408-413$.

44. Miranda-Trevino, J.C.; Coles, C.A. Kaolinite properties, structure and influence of metal retention on pH. Appl. Clay Sci. 2003, 23, 133-139. [CrossRef]

45. Li, J.Y.; Xu, R.K. Inhibition of acidification of kaolinite and an Alfisol by aluminum oxides through electrical double-layer interaction and coating. Eur. J. Soil Sci. 2013, 64, 110-120. [CrossRef]

46. Juo, A.S.; Franzluebbers, K. Properties and Management of Oxidic Soils. In Tropical Soils; Oxford University Press: Oxford, UK, 2003.

47. Soil Survey Staff. Keys to Soil Taxonomy, 11th ed.; USDA/NRCS; U.S. Government Printing Office: Washington, DC, USA, 2010.

48. Motavalli, P.P.; Palm, C.A.; Parton, W.J.; Elliott, E.T.; Frey, S.D. Soil pH and organic C dynamics in tropical forest soils: Evidence from laboratory and simulation studies. Soil Biol. Biochem. 1995, 27, 1589-1599. [CrossRef]

49. da Costa Severiano, E.; de Oliveira, G.C.; Junior, M.D.S.D.; Curi, N.; de Pinho Costa, K.A.; Carducci, C.E. Preconsolidation pressure, soil water retention characteristics, and texture of Latosols in the Brazilian Cerrado. Soil Res. 2013, 51, 193-202. [CrossRef]

50. Silva, B.M.; Oliveira, G.C.; Serafim, M.E.; Silva, E.A.; Ferreira, M.M.; Norton, L.D.; Curi, N. Critical soil moisture range for a coffee crop in an oxidic Latosol as affected by soil management. Soil Tillage Res. 2015, 154, 103-113. [CrossRef]

51. Taylor, R.K.; Smith, T.J. The engineering geology of clay minerals: Swelling, shrinking and mudrock breakdown. Clay Miner. 1986, 21, 235-260. [CrossRef]

52. Thomas, P.J.; Baker, J.C.; Zelazny, L.W. An expansive soil index for predicting shrink-swell potential. Soil Sci. Soc. Am. J. 2000, 64, 268-274. [CrossRef]

53. Kariuki, P.C.; Van Der Meer, F.; Verhoef, P.N.W. Cation exchange capacity (CEC) determination from spectroscopy. Int. J. Remote Sens. 2003, 24, 161-167. [CrossRef] 
54. Reid-Soukup, D.A.; Ulery, A.L. Smectites. Soil Mineral. Environ. Appl. 2002, 7, 467-499.

55. Środon, J.; MaCarty, D.K. Surface area and layer charge of smectite from CEC and EGME/H2O-retention measurements. Clays Clay Miner. 2008, 56, 155-174. [CrossRef]

56. Borchardt, G. Smectites. Miner. Soil Environ. 1989, 1, 675-727.

57. Juo, A.S.; Franzluebbers, K. Properties and Management of Smectitic Soils. In Tropical Soils; Oxford University Press: Oxford, UK, 2003. [CrossRef]

58. Bowers, G.M.; Loring, J.S.; Walter, E.D.; Burton, S.D.; Bowden, M.E.; Hoyt, D.W.; Kirkpatrick, R.J. Influence of smectite structure and hydration on supercritical methane binding and dynamics in smectite pores. J. Phys. Chem. C 2019, 123, 29231-29244. [CrossRef]

59. Taylor, R.K. Cation exchange in clays and mudrocks by methylene blue. J. Chem. Technol. Biotechnol. Chem. Technol. 1985, 35, 195-207. [CrossRef]

60. Delmelle, P.; Opfergelt, S.; Cornelis, J.T.; Ping, C.L. Volcanic soils. In The Encyclopedia of Volcanoes; Academic Press: Cambridge, MA, USA, 2015; pp. 1253-1264.

61. Hewitt, A.; Dymond, J. Survey of New Zealand soil orders. In Cosystem Services in New Zealand—Conditions and Trend; Dymond, J.R., Ed.; Manaaki Whenua Press: Lincoln, New Zealand, 2013; Volume 1, pp. 121-131.

62. Nath, T.N. Soil texture and total organic matter content and its influences on soil water holding capacity of some selected tea growing soils in Sivasagar district of Assam, India. Int. J. Chem. Sci 2014, 12, 1419-1429.

63. Jones, C.; Jacobsen, J. Plant nutrition and soil fertility. Nutr. Manag. Modul. 2005, 2, 1-11.

64. Suzuki, S.; Noble, A.D.; Ruaysoongnern, S.; Chinabut, N. Improvement in water-holding capacity and structural stability of a sandy soil in Northeast Thailand. Arid Land Res. Manag. 2007, 21, 37-49. [CrossRef]

65. Basso, A.S.; Miguez, F.E.; Laird, D.A.; Horton, R.; Westgate, M. Assessing potential of biochar for increasing water-holding capacity of sandy soils. GCB Bioenergy 2013, 5, 132-143. [CrossRef]

66. McCauley, A.; Jones, C.; Jacobsen, J. Basic soil properties. Soil Water Manag. Modul. 2005, 1, 1-12.

67. Troeh, F.R.; Thompson, L.M. Soils and Soil Fertility; Blackwell: New York, NY, USA, 2005; Volume 489.

68. Hasbullah. Use of Clinoptilolite Zeolite to Improve Efficiency of Phosphorus Use in Acid Soils. Ph.D. Thesis, University Putra Malaysia, Serdang, Selangor, Malaysia, 2016.

69. Malvi, U.R. Interaction of micronutrients with major nutrients with special reference to potassium. Karnataka J. Agric. Sci. 2011, 24, 106-109.

70. Allison, F.E. Soil Organic Matter and Its Role in Crop Production; Elsevier: Amsterdam, The Netherlands, 1973.

71. Gleixner, G.; Poirier, N.; Bol, R.; Balesdent, J. Molecular dynamics of organic matter in a cultivated soil. Org. Geochem. 2002, 33, 357-366. [CrossRef]

72. Franzluebbers, A.J. Water infiltration and soil structure related to organic matter and its stratification with depth. Soil Tillage Res. 2002, 66, 197-205. [CrossRef]

73. Aprile, F.; Lorandi, R. Evaluation of cation exchange capacity (CEC) in tropical soils using four different analytical methods. $J$. Agric. Sci. 2012, 4, 278. [CrossRef]

74. Binkley, D.; Valentine, D.; Wells, C.; Valentine, U. An empirical analysis of the factors contributing to 20-year decrease in soil pH in an old-field plantation of loblolly pine. Biogeochemistry 1989, 8, 39-54. [CrossRef]

75. Simonsson, M.; Hillier, S.; Öborn, I. Changes in clay minerals and potassium fixation capacity as a result of release and fixation of potassium in long-term field experiments. Geoderma 2009, 151, 109-120. [CrossRef]

76. Mikkelsen, R. The importance of potassium management for horticultural crops. Indian J. Fertile. 2017, $13,82-86$.

77. Ganeshamurthy, A.N.; Satisha, G.C.; Patil, P. Potassium nutrition on yield and quality of fruit crops with special emphasis on banana and grapes. Karnataka J. Agric. Sci. 2011, 24, 29-38.

78. Srinivasarao, C.; Singh, R.N.; Ganeshamurthy, A.N.; Ghansham, S.; Masood, A. Fixation and recovery of added phosphorus and potassium in different soil types of pulse-growing regions of India. Commun. Soil Sci. Plant Anal. 2007, 38, 449-460. [CrossRef]

79. Meena, V.S.; Maurya, B.R.; Verma, J.P. Does a rhizospheric microorganism enhance K+ availability in agricultural soils? Microbiol. Res. 2014, 169, 337-347. [CrossRef]

80. Kumar, S.; Dhar, S.; Kumar, A.; Kumar, D. Yield and nutrient uptake of maize (Zea mays)-wheat (Triticum aestivum) cropping system as influenced by integrated potassium management. Indian J. Agron. 2015, 60, 511-515.

81. Wang, M.; Zheng, Q.; Shen, Q.; Guo, S. The critical role of potassium in plant stress response. Int. J. Mol. Sci. 2013, 14, 7370-7390. [CrossRef] [PubMed]

82. Hamdallah, G. Plant, animal and human nutrition: An intricate relationship. In Regional Expert Consultation on Land Degradation, Plant, Animal and Human Nutrition; The Food and Agriculture Organization (FAO): Damascus, Syria, 2005.

83. Panaullah, G.M.; Timsina, J.; Saleque, M.A.; Ishaque, M.; Pathan, A.B.M.B.U.; Connor, D.J.; Saha, P.K.; Quayyum, M.A.; Humphreys, E.; Meisner, C.A. Nutrient uptake and apparent balances for rice-wheat sequences. III. Potassium. J. Plant Nutr. 2006, 29, 173-187. [CrossRef]

84. Andrist Rangel, Y. Quantifying Mineral Sources of Potassium in Agricultural Soils. Ph.D. Thesis, Swedish University of Agricultural Sciences, Uppsala, Sweden, 2008.

85. Sparks, D.L. Bioavailability of soil potassium, D-38-D-52. In Handbook of Soil Science; Sumner, M.E., Ed.; CRC Press: Boca Raton, FL, USA, 2000. 
86. Jaiswal, D.K.; Verma, J.P.; Prakash, S.; Meena, V.S.; Meena, R.S. Potassium as an important plant nutrient in sustainable agriculture: A state of the art. In Potassium Solubilizing Microorganisms for Sustainable Agriculture; Springer: Berlin/Heidelberg, Germany, 2016; pp. 21-29.

87. Sumner, M.E. Handbook of Soil Science; CRC Press: Boca Raton, FL, USA, 1999.

88. Darunsontaya, T.; Suddhiprakarn, A.; Kheoruenromne, I.; Prakongkep, N.; Gilkes, R.J. The forms and availability to plants of soil potassium as related to mineralogy for upland Oxisols and Ultisols from Thailand. Geoderma 2012, 170, 11-24. [CrossRef]

89. Wang, H.Y.; Zhou, J.M.; Du, C.W.; Chen, X.Q. Potassium fractions in soils as affected by monocalcium phosphate, ammonium sulfate, and potassium chloride application. Pedosphere 2010, 20, 368-377. [CrossRef]

90. Kundu, M.C.; Hazra, G.C.; Biswas, P.K.; Mondal, S.; Ghosh, G.K. Forms and distribution of potassium in some soils of Hooghly district of West Bengal. J. Crop. Weed 2014, 10, 31-37.

91. Pavlov, K.V. The assessment of the potassium status of soil by the proportion between different forms of potassium. Eurasian Soil Sci. 2007, 40, 792-794. [CrossRef]

92. Zeng, Q.; Brown, P.H. Soil potassium mobility and uptake by corn under differential soil moisture regimes. Plant Soil 2000, 221, 121-134. [CrossRef]

93. Sparks, D.L.; Huang, P.M. Physical chemistry of soil potassium. In Potassium in Agriculture; American Society of Agronomy: Madison, WI, USA, 1985; pp. 201-276.

94. Sparks, D.L. Potassium dynamics in soils. In Advances in Soil Science; Springer: New York, NY, USA, $1987 ;$ pp. 1-63.

95. Kirkman, J.H.; Basker, A.; Surapaneni, A.; MacGregor, A.N. Potassium in the soils of New Zealand-A review. N. Z. J. Agric. Res. 1994, 37, 207-227. [CrossRef]

96. Parfitt, R.L. Potassium-calcium exchange in some New Zealand soils. Soil Res. 1992, 30, 145-158. [CrossRef]

97. Huoyan, W.; Cheng, W.; Ting, L.I.; Jianmin, Z.; Xiaoqin, C. Can nonexchangeable potassium be differentiated from structural potassium in soils? Pedosphere 2016, 26, 206-215.

98. Srinivasarao, C.; Khera, M.S. Effect of exhaustive cropping on various potassium forms. J. Potassium Res. 1994, 10, 109-116.

99. Rao, C.S.; Prasad, V.B.; Prasad, P.R.K.; Bansav, S.K.; Rao, A.S.; Takkar, P.N. An Assessment of Potassium Reserves and K Desorption in Micaceous Alfisols and Inceptisols Using Conventional Estimates and Electroultrafiltration. J. Indian Soc. Soil Sci. 1997, 45, 44-47.

100. Metson, A.J. Potassium in New Zealand soils. N. Z. Soil Bur. Sci. Rep. 1980, 38, 207-227.

101. Rao, C.S.; Rao, A.S.; Rao, K.V.; Venkateswarlu, B.; Singh, A.K. Categorisation of districts based on nonexchangeable potassium: Implications in efficient $\mathrm{K}$ fertility management in Indian agriculture. Indian J. Fertile. 2010, 6, 40-54.

102. Smith, C.W.; Dilday, R.H. Rice: Origin, History, Technology, and Production; Wiley Series in Crop Science; John Wiley \& Sons: Hoboken, NJ, USA, 2002.

103. Schneider, A.; Tesileanu, R.; Charles, R.; Sinaj, S. Kinetics of soil potassium sorption-desorption and fixation. Commun. Soil Sci. Plant Anal. 2013, 44, 837-849. [CrossRef]

104. Rich, C.I. Mineralogy of soil potassium. In Role of Potassium in Agriculture; American Society of Agronomy: Madison, WI, USA, 1968; pp. 79-108.

105. Bangar, K. Distribution of Different Forms of Potassium (K) in Surface and Sub-suface Soils of Agriculture College Farm, Indore. Ph.D. Thesis, Rajmata Vijayaraje Scindia Krishi Vishwa Vidyalaya (RVSKVV), Gwalior, MP, India, 2015.

106. Reddy, K.R.; D'Angelo, E.M.; Harris, W.G. Biogeochemistry of wetlands. In Handbook of Soil Science; Sumner, M.E., Ed.; CRC Press: Boca Raton, FL, USA, 2000; pp. G89-G119.

107. Öborn, I.; Andrist-Rangel, Y.; Askekaard, M.; Grant, C.A.; Watson, C.A.; Edwards, A.C. Critical aspects of potassium management in agricultural systems. Soil Use Manag. 2005, 21, 102-112. [CrossRef]

108. Liang, B.; Lehmann, J.; Solomon, D.; Kinyangi, J.; Grossman, J.; O'neill, B.; Neves, E.G. Black carbon increases cation exchange capacity in soils. Soil Sci. Soc. Am. J. 2006, 70, 1719-1730. [CrossRef]

109. Raju, R.A. Glimpses of Rice Technology; Agrobios: Jodhpur, India, 2003.

110. Nanda, J.S.; Agrawal, P.K. Rice; Kalyani Publishers: New Delhi, India, 2006.

111. Jiang, Y.; Yan, J. Effects of land use on hydrochemistry and contamination of Karst groundwater from Nandong underground river system, China. Water Air Soil Pollut. 2010, 210, 123-141. [CrossRef]

112. Lu, Q.; He, Z.L.; Stoffella, P.J. Land application of biosolids in the USA: A review. Appl. Environ. Soil Sci. 2012, $2012,201462$. [CrossRef]

113. Larney, F.J.; Angers, D.A. The role of organic amendments in soil reclamation: A review. Can. J. Soil Sci. 2012, 92, 19-38. [CrossRef]

114. Munksgaard, N.C.; Lottermoser, B.G. Phosphate amendment of metalliferous tailings, Cannington Ag-Pb-Zn mine, Australia: Implications for the capping of tailings storage facilities. Environ. Earth Sci. 2013, 68, 33-44. [CrossRef]

115. Scotti, R.; Bonanomi, G.; Scelza, R.; Zoina, A.; Rao, M.A. Organic amendments as sustainable tool to recovery fertility in intensive agricultural systems. J. Soil Sci. Plant Nutr. 2015, 15, 333-352. [CrossRef]

116. Andersen, D.S.; Pepple, L.M. A county-level assessment of manure nutrient availability relative to crop nutrient capacity in Iowa: Spatial and temporal trends. Trans. ASABE 2017, 60, 1669-1680. [CrossRef]

117. Alvarez, C.E.; Amin, M.; Hernández, E.; González, C.J. Effect of compost, farmyard manure and/or chemical fertilizers on potato yield and tuber nutrient content. Biol. Agric. Hortic. 2006, 23, 273-286. [CrossRef] 
118. Otieno, H.M.; Zingore, G.N.C.W.S. Effect of farmyard manure, lime and inorganic fertilizer applications on soil pH, nutrients uptake, growth and nodulation of soybean in acid soils of western Kenya. J. Agric. Sci. 2018, 10. [CrossRef]

119. Meek, B.; Graham, L.; Donovan, T. Long-term effects of manure on soil nitrogen, phosphorus, potassium, sodium, organic matter, and water infiltration rate. Soil Sci. Soc. Am. J. 1982, 46, 1014-1019. [CrossRef]

120. De Ridder, N.; Van Keulen, H. Some aspects of the role of organic matter in sustainable intensified arable farming systems in the West-African semi-arid-tropics (SAT). Fertil. Res. 1990, 26, 299-310. [CrossRef]

121. Hoffmann, I.; Gerling, D.; Kyiogwom, U.B.; Mané-Bielfeldt, A. Farmers' management strategies to maintain soil fertility in a remote area in northwest Nigeria. Agric. Ecosyst. Environ. 2001, 86, 263-275. [CrossRef]

122. Goladi, J.T.; Agbenin, J.O. The cation exchange properties and microbial carbon, nitrogen and phosphorus in savanna Alfisol under continuous cultivation. J. Sci. Food Agric. 1997, 75, 412-418. [CrossRef]

123. Bolan, N.S.; Szogi, A.A.; Chuasavathi, T.; Seshadri, B.; Rothrock, M.J.; Panneerselvam, P. Uses and management of poultry litter. World's Poult. Sci. J. 2010, 66, 673-698. [CrossRef]

124. Bolan, N.; Adriano, D.; Mahimairaja, S. Distribution and bioavailability of trace elements in livestock and poultry manure by-products. Crit. Rev. Environ. Sci. Technol. 2004, 34, 291-338. [CrossRef]

125. Chadwick, D.R.; Pain, B.F.; Brookman, S.K.E. Nitrous oxide and methane emissions following application of animal manures to grassland. J. Environ. Qual. 2000, 29, 277-287. [CrossRef]

126. Qaswar, M.; Yiren, L.; Jing, H.; Kaillou, L.; Mudasir, M.; Zhenzhen, L.; Hongqian, H.; Xianjin, L.; Jianhua, J.; Ahmed, W.; et al. Soil nutrients and heavy metal availability under long-term combined application of swine manure and synthetic fertilizers in acidic paddy soil. J. Soils Sediments 2020, 20, 2093-2106. [CrossRef]

127. Paul, K.I.; Black, A.S.; Conyers, M.K. Effect of plant residue return on the development of surface soil pH gradients. Biol. Fertil. Soils 2001, 33, 75-82. [CrossRef]

128. Lal, R. Crop residues as soil amendments and feedstock for bioethanol production. Waste Manag. 2008, 28, 747-758. [CrossRef] [PubMed]

129. Raimbault, B.A.; Vyn, T.J. Crop rotation and tillage effects on corn growth and soil structural stability. Agron. J. 1991, 83, 979-985. [CrossRef]

130. Yokelson, R.J.; Burling, I.R.; Urbanski, S.P.; Atlas, E.L.; Adachi, K.; Buseck, P.R.; Wiedinmyer, C.; Akagi, S.K.; Toohey, D.W.; Wold, C.E. Trace gas and particle emissions from open biomass burning in Mexico. Atmos. Chem. Phys. 2011, 11, 6787-6808. [CrossRef]

131. Mikkelsen, R. Ammonia emissions from agricultural operations: Fertilizer. Better Crop 2009, 93, 9-11.

132. Baggs, E.M.; Rees, R.M.; Smith, K.A.; Vinten, A.J.A. Nitrous oxide emission from soils after incorporating crop residues. Soil Use Manag. 2000, 16, 82-87. [CrossRef]

133. Benitez, C.; Tejada, M.; Gonzalez, J.L. Kinetics of the mineralization of nitrogen in a pig slurry compost applied to soils. Compos. Sci. Util. 2003, 11, 72-80. [CrossRef]

134. AyanfeOluwa, O.E.; AdeOluwa, O.O.; Aduramigba-Modupe, V.O. Nutrient release dynamics of an accelerated compost: A case study in an Alfisol and Ultisol. Eurasian J. Soil Sci. 2017, 6, 350-356. [CrossRef]

135. Litaor, M.I.; Katz, L.; Shenker, M. The influence of compost and zeolite co-addition on the nutrients status and plant growth in intensively cultivated Mediterranean soils. Soil Use Manag. 2017, 33, 72-80. [CrossRef]

136. Dias, B.O.; Silva, C.A.; Higashikawa, F.S.; Roig, A.; Sánchez-Monedero, M.A. Use of biochar as bulking agent for the composting of poultry manure: Effect on organic matter degradation and humification. Bioresour. Technol. 2010, 101, 1239-1246. [CrossRef]

137. Chan, Y.C.; Sinha, R.K.; Wang, W. Emission of greenhouse gases from home aerobic composting, anaerobic digestion and vermicomposting of household wastes in Brisbane (Australia). Waste Manag. Res. 2011, 29, 540-548. [CrossRef] [PubMed]

138. Hao, X.; Chang, C.; Larney, F.J. Carbon, nitrogen balances and greenhouse gas emission during cattle feedlot manure composting. J. Environ. Qual. 2004, 33, 37-44. [CrossRef] [PubMed]

139. O’Hallorans, J.M.; Muñoz, M.A.; Márquez, P.E. Chicken manure as an amendment to correct soil acidity and fertility. J. Agric. Univ. Puerto Rico 1997, 81, 1-8.

140. Rafique, E.; Mahmood-ul-Hassan, M.; Rashid, A.; Chaudhary, M.F. Nutrient balances as affected by integrated nutrient and crop residue management in cotton-wheat system in Aridisols. III. Potassium. J. Plant Nutr. 2012, 35, 633-648. [CrossRef]

141. Roy, S.; Kashem, M.A.; Osman, K.T. The uptake of phosphorous and potassium of rice as affected by different water and organic manure management. J. Plant Sci. 2018, 6, 31-40.

142. Kasongo, R.K.; Verdoodt, A.; Kanyankagote, P.; Baert, G.; Ranst, E.V. Coffee waste as an alternative fertilizer with soil improving properties for sandy soils in humid tropical environments. Soil Use Manag. 2011, 27, 94-102. [CrossRef]

143. Meli, S.M.; Baglieri, A.; Porto, M.; Belligno, A.; Gennari, M. Chemical and microbiological aspects of soil amended with citrus pulp. J. Sustain. Agric. 2007, 30, 53-66. [CrossRef]

144. Meena, M.D.; Biswas, D.R. Phosphorus and potassium transformations in soil amended with enriched compost and chemical fertilizers in a wheat-soybean cropping system. Commun. Soil Sci. Plant Anal. 2014, 45, 624-652. [CrossRef]

145. Qian, P.; Schoenau, J.J.; King, T.; Japp, M. Effect of repeated manure application on potassium, calcium and magnesium in soil and cereal crops in Saskatchewan. Can. J. Soil Sci. 2005, 85, 397-403. [CrossRef]

146. Sarker, A.; Kashem, A.; Osman, K.T. Influence of city finished compost and nitrogen, phosphorus and potassium (NPK) fertilizer on yield, nutrient uptake and nutrient use efficiency of radish (Raphanus sativus L.) in an acid soil. Int. J. Agric. Sci. 2012, 2, 315-321. 
147. Whalen, J.K.; Chang, C.; Clayton, G.W.; Carefoot, J.P. Cattle manure amendments can increase the pH of acid soils. Soil Sci. Soc. Am. J. 2000, 64, 962-966. [CrossRef]

148. MacCarthy, P. The principles of humic substances. Soil Sci. 2001, 166, 738-751. [CrossRef]

149. Piccolo, A. The supramolecular structure of humic substances: A novel understanding of humus chemistry and implications in soil science. Adv. Agron. 2002, 75, 57-134.

150. Schaumann, G.E. Soil organic matter beyond molecular structure Part I: Macromolecular and supramolecular characteristics. J. Plant Nutr. Soil Sci. 2006, 169, 145-156. [CrossRef]

151. Piccolo, A. The supramolecular structure of humic substances. Soil Sci. 2001, 166, 810-832. [CrossRef]

152. Sutton, R.; Sposito, G. Molecular structure in soil humic substances: The new view. Environ. Sci. Technol. 2005, 39, 9009-9015. [CrossRef] [PubMed]

153. Pinton, R.; Cesco, S.; Varanini, Z. Role of Humic Substances in the Rhizosphere. In Biophysico-Chemical Processes Involving Natural Nonliving Organic Matter in Environmental Systems; Senesi, N., Xing, B., Huang, P.M., Eds.; John Wiley \& Sons: Hoboken, NJ, USA, 2009; pp. 341-366.

154. Stevenson, F.J. Humus Chemistry: Genesis, Composition, Reactions; John Wiley \& Sons: Hoboken, NJ, USA, 1994.

155. Piccolo, A.; Cozzolino, A.; Conte, P.; Spaccini, R. Polymerization of humic substances by an enzyme-catalyzed oxidative coupling. Naturwissenschaften 2000, 87, 391-394. [CrossRef] [PubMed]

156. Baldock, J.A.; Broos, K. Handbook of Soil Sciences: Resource Management and Environmental Impacts; Huang, P.M., Li, Y., Sumner, M.E., Eds.; CRC Press: Boca Raton, FL, USA, 2011.

157. Hatcher, P.G. The CHNs of organic geochemistry: Characterization of molecularly uncharacterized non-living organic matter. Mar. Chem. 2004, 92, 5-8. [CrossRef]

158. Waksman, S.A. Humus: Origin, Chemical Composition and Importance in Nature; Williams and Wilkins: Philadelphia, PA, USA, 1936.

159. Ghabbour, E.A.; Davies, G.; Davies, G. Humic Substances: Structures, Models and Functions; Royal Society of Chemistry: Cambridge, UK, 2001; p. 273.

160. Chung, K.H.; Choi, G.S.; Shin, H.S.; Lee, C.W. Vertical distribution and characteristics of soil humic substances affecting radionuclide distribution. J. Environ. Radioact. 2005, 79, 369-379. [CrossRef] [PubMed]

161. Baglieri, A.; Ioppolo, A.; Negre, M.; Gennari, M. A method for isolating soil organic matter after the extraction of humic and fulvic acids. Org. Geochem. 2007, 38, 140-150. [CrossRef]

162. Zavarzina, A.G.; Vanifatova, N.G.; Stepanov, A.A. Fractionation of humic acids according to their hydrophobicity, size, and charge-dependent mobility by the salting-out method. Eurasian Soil Sci. 2008, 41, 1294-1301. [CrossRef]

163. Semenov, V.M.; Tulina, A.S.; Semenova, N.A.; Ivannikova, L.A. Humification and nonhumification pathways of the organic matter stabilization in soil: A review. Eurasian Soil Sci. 2013, 46, 355-368. [CrossRef]

164. Pettit, R.E. Organic matter, humus, humate, humic acid, fulvic acid and humin: Their importance in soil fertility and plant health. CTI Res. 2004, 10, 1-7.

165. Schulten, H.R.; Leinweber, P. New insights into organic-mineral particles: Composition, properties and models of molecular structure. Biol. Fertil. Soils 2000, 30, 399-432. [CrossRef]

166. Schulten, H.R. Models of humic structures: Association of humic acids and organic matter in soils and water. In Humic Substances and Chemical Contaminants; American Society of Agronomy: Madison, WI, USA, 2001; pp. 73-87.

167. Kujawinski, E.B.; Hatcher, P.G.; Freitas, M.A. High-resolution Fourier transform ion cyclotron resonance mass spectrometry of humic and fulvic acids: Improvements and comparisons. Anal. Chem. 2002, 74, 413-419. [CrossRef]

168. Stenson, A.C.; Landing, W.M.; Marshall, A.G.; Copper, W.T. Ionization and fragmentation of humic substances in electrospray ionization Fourier transform-ion cyclotron resonance mass spectrometry. Anal. Chem. 2002, 74, 4397-4409. [CrossRef] [PubMed]

169. Stenson, A.C.; Marshall, A.G.; Copper, W.T. Exact masses and chemical formulas of individual suwannee river fulvic acids from ultrahigh resolution ESI FT-ICR mass spectra. Anal. Chem. 2003, 75, 1275-1284. [CrossRef]

170. Baldock, J.A.; Oades, J.M.; Waters, A.G.; Peng, X.; Vassallo, A.M.; Wilson, M.A. Aspects of the chemical structure of soil organic materials as revealed by solid-state 13 C NMR spectroscopy. Biogeochemistry 1992, 16, 1-42. [CrossRef]

171. Novak, J.; Kozler, J.; Janos, P.; Cezíkova, J.; Tokarova, V.; Madronova, L. Humic acids from coals of the North-Bohemian coal field: I. Preparation and characterisation. React. Funct. Polym. 2001, 47, 101-109. [CrossRef]

172. Eyheraguibel, B.; Silvestre, J.; Morard, P. Effects of humic substances derived from organic waste enhancement on the growth and mineral nutrition of maize. Bioresour. Technol. 2008, 99, 4206-4212. [CrossRef] [PubMed]

173. Beznosikov, V.A.; Lodygin, E.D. Characteristics of the structure of humic substances of podzolic and peaty podzolic gleyey soils. Russ. Agric. Sci. 2009, 35, 103-105. [CrossRef]

174. Rivero, C.; Chirenje, T.; Ma, L.Q.; Martinez, G. Influence of compost on soil organic matter quality under tropical conditions. Geoderma 2004, 123, 355-361. [CrossRef]

175. Tan, K.H. Humic Matter in Soil and the Environment: Principles and Controversies; CRC Press: Boca Raton, FL, USA, 2003.

176. Kulikova, N.A.; Stepanova, E.V.; Koroleva, O.V. Mitigating activity of humic substances: Direct influence on biota. In Use of Humic Substances to Remediate Polluted Environments: From Theory to Practice; Springer: Berlin, Germany, 2005; pp. 285-309.

177. Calace, N.; Petronio, B.M.; Persia, S.; Pietroletti, M.; Pacioni, D. A new analytical approach for humin determination in sediments and soils. Talanta 2007, 71, 1444-1448. [CrossRef] 
178. Tatzber, M.; Stemmer, M.; Spiegel, H.; Katzlberger, C.; Haberhauer, G.; Mentler, A.; Gerzabek, M.H. FTIR-spectroscopic characterization of humic acids and humin fractions obtained by advanced $\mathrm{NaOH}, \mathrm{Na}_{4} \mathrm{P}_{2} \mathrm{O}_{7}$, and $\mathrm{Na}_{2} \mathrm{CO}_{3}$ extraction procedures. J. Plant Nutr. Soil Sci. 2007, 170, 522-529. [CrossRef]

179. Hayes, M.H.; Graham, C.L. Procedures for the isolation and fractionation of humic substances. In Humic Substances; Woodhead Publishing: Sawston, UK, 2000; pp. 91-109.

180. Illés, E.; Tombácz, E. The role of variable surface charge and surface complexation in the adsorption of humic acid on magnetite. Colloids Surf. A Physicochem. Eng. Asp. 2003, 230, 99-109. [CrossRef]

181. Gauthier, T.D.; Seitz, W.R.; Grant, C.L. Effects of structural and compositional variations of dissolved humic materials on pyrene Koc values. Environ. Sci. Technol. 1987, 21, 243-248. [CrossRef]

182. Wershaw, R.L. A new model for humic materials and their interactions with hydrophobic organic chemicals in soil-water or sediment-water systems. J. Contam. Hydrol. 1986, 1, 29-45. [CrossRef]

183. Rice-Evans, C.A.; Miller, N.J.; Paganga, G. Structure-antioxidant activity relationships of flavonoids and phenolic acids. Free Radic. Biol. Med. 1996, 20, 933-956. [CrossRef]

184. Calvin, M. Hydrocarbons via photosynthesis. Int. J. Energy Res. 1977, 1, 299-327. [CrossRef]

185. Cornejo, J.; Hermosin, M.C. Interaction of humic substances and soil clays. In Humic Substances in Terrestrial Ecosystems; Elsevier: Amsterdam, The Netherlands, 1996; pp. 595-624.

186. Bot, A.; Benites, J. The Importance of Soil Organic Matter: Key to Drought-Resistant Soil and Sustained Food Production; FAO Soils Bulletin 80; FAO: Rome, Italy, 2005.

187. Bradl, H. Heavy Metals in the Environment: Origin, Interaction and Remediation; Elsevier: Amsterdam, The Netherlands, 2005.

188. Tipping, E. Cation Binding by Humic Substances; Cambridge University Press: Cambridge, UK, 2002 ; Volume 12.

189. Read, P.; Lermit, J. Bio-energy with carbon storage (BECS): A sequential decision approach to the threat of abrupt climate change. Energy 2005, 30, 2654-2671. [CrossRef]

190. Schmidt, M.W.; Noack, A.G. Black carbon in soils and sediments: Analysis, distribution, implications, and current challenges. Glob. Biogeochem. Cycles 2000, 14, 777-793. [CrossRef]

191. Antal, M.J.; Grønli, M. The art, science, and technology of charcoal production. Ind. Eng. Chem. Res. 2003, 42, 1619-1640. [CrossRef]

192. Demirbas, A. Effects of temperature and particle size on bio-char yield from pyrolysis of agricultural residues. J. Anal. Appl. Pyrolysis 2004, 72, 243-248. [CrossRef]

193. Boateng, A.A. Characterization and thermal conversion of charcoal derived from fluidized-bed fast pyrolysis oil production of switchgrass. Ind. Eng. Chem. Res. 2007, 46, 8857-8862. [CrossRef]

194. Amonette, J.E.; Joseph, S. Characteristics of biochar: Microchemical properties. In Biochar for Environmental Management; Routledge: London, UK, 2012; pp. 65-84.

195. Baldock, J.A.; Smernik, R.J. Chemical composition and bioavailability of thermally altered Pinus resinosa (Red pine) wood. Org. Geochem. 2002, 33, 1093-1109. [CrossRef]

196. Biederman, L.A.; Harpole, W.S. Biochar and its effects on plant productivity and nutrient cycling: A meta-analysis. GCB Bioenergy 2013, 5, 202-214. [CrossRef]

197. Major, J.; Rondon, M.; Molina, D.; Riha, S.J.; Lehmann, J. Maize yield and nutrition during 4 years after biochar application to a Colombian savanna oxisol. Plant Soil 2010, 333, 117-128. [CrossRef]

198. Atkinson, C.J.; Fitzgerald, J.D.; Hipps, N.A. Potential mechanisms for achieving agricultural benefits from biochar application to temperate soils: A review. Plant Soil 2010, 337, 1-18. [CrossRef]

199. Lehmann, J. Bio-energy in the black. Front. Ecol. Environ. 2007, 5, 381-387. [CrossRef]

200. Yao, Y.; Gao, B.; Zhang, M.; Inyang, M.; Zimmerman, A.R. Effect of biochar amendment on sorption and leaching of nitrate, ammonium, and phosphate in a sandy soil. Chemosphere 2012, 89, 1467-1471. [CrossRef]

201. Steiner, C.; Teixeira, W.G.; Lehmann, J.; Nehls, T.; de Macêdo, J.L.V.; Blum, W.E.; Zech, W. Long term effects of manure, charcoal and mineral fertilization on crop production and fertility on a highly weathered Central Amazonian upland soil. Plant Soil 2007, 291, 275-290. [CrossRef]

202. Glaser, B.; Lehmann, J.; Zech, W. Ameliorating physical and chemical properties of highly weathered soils in the tropics with charcoal-A review. Biol. Fertil. Soils 2002, 35, 219-230. [CrossRef]

203. Khan, M.A.; Kim, K.W.; Mingzhi, W.; Lim, B.K.; Lee, W.H.; Lee, J.Y. Nutrient-impregnated charcoal: An environmentally friendly slow-release fertilizer. Environmentalist 2008, 28, 231-235. [CrossRef]

204. de Sousa, Á.M.B.; Soares Santos, R.R.; Gehring, C. Charcoal in Amazonian paddy soil—Nutrient availability, rice growth and methane emissions. J. Plant Nutr. Soil Sci. 2014, 177, 39-47. [CrossRef]

205. Lehmann, J.; da Silva, J.P.; Steiner, C.; Nehls, T.; Zech, W.; Glaser, B. Nutrient availability and leaching in an archaeological Anthrosol and a Ferralsol of the Central Amazon basin: Fertilizer, manure and charcoal amendments. Plant Soil 2003, 249, 343-357. [CrossRef]

206. Glaser, B.; Wiedner, K.; Seelig, S.; Schmidt, H.P.; Gerber, H. Biochar organic fertilizers from natural resources as substitute for mineral fertilizers. Agron. Sustain. Dev. 2015, 35, 667-678. [CrossRef]

207. Castellini, M.; Giglio, L.; Niedda, M.; Palumbo, A.D.; Ventrella, D. Impact of biochar addition on the physical and hydraulic properties of a clay soil. Soil Tillage Res. 2015, 154, 1-13. [CrossRef] 
208. Verheijen, F.G.A.; Jones, R.J.A.; Rickson, R.J.; Smith, C.J. Tolerable versus actual soil erosion rates in Europe. Earth Sci. Rev. 2009, 94, 23-38. [CrossRef]

209. Verheijen, F.; Jeffery, S.; Bastos, A.C.; Van der Velde, M.; Diafas, I. Biochar Application to Soils-A Critical Scientific Review of Effects on Soil Properties, Processes, and Functions; EUR 24099 EN; European Commission: Brussels, Belgium, 2010; p. 162.

210. Tan, Z.; Lin, C.S.; Ji, X.; Rainey, T.J. Returning biochar to fields: A review. Appl. Soil Ecol. 2017, 116, 1-11. [CrossRef]

211. Jones, D.L.; Edwards-Jones, G.; Murphy, D.V. Biochar mediated alterations in herbicide breakdown and leaching in soil. Soil Biol. Biochem. 2011, 43, 804-813. [CrossRef]

212. Khorram, M.S.; Zhang, Q.; Lin, D.; Zheng, Y.; Fang, H.; Yu, Y.L. Biochar: A review of its impact on pesticide behavior in soil environments and its potential applications. J. Environ. Sci. 2016, 44, 269-279. [CrossRef]

213. Kookana, R.S. The role of biochar in modifying the environmental fate, bioavailability, and efficacy of pesticides in soils: A review. Soil Res. 2010, 48, 627. [CrossRef]

214. Zhang, Q.M.; Saleem, M.; Wang, C.X. Effects of biochar on the earthworm (Eisenia foetida) in soil contaminated with and/or without pesticide mesotrione. Sci. Total Environ. 2019, 671, 52-58. [CrossRef]

215. Pitman, R.M. Wood ash use in forestry-A review of the environmental impacts. For. Int. J. For. Res. 2006, 79, 563-588. [CrossRef]

216. Park, B.B.; Yanai, R.D.; Sahm, J.M.; Lee, D.K.; Abrahamson, L.P. Wood ash effects on plant and soil in a willow bioenergy plantation. Biomass Bioenergy 2005, 28, 355-365. [CrossRef]

217. Etiegni, L.; Campbell, A.G.; Mahler, R.L. Evaluation of wood ash disposal on agricultural land. I. Potential as a soil additive and liming agent. Commun. Soil Sci. Plant Anal. 1991, 22, 243-256. [CrossRef]

218. Huang, H.; Campbell, A.G.; Folk, R.; Mahler, R.L. Wood ash as a soil additive and liming agent for wheat: Field studies. Commun. Soil Sci. Plant Anal. 1992, 23, 25-33. [CrossRef]

219. Unger, Y.L.; Fernandez, I.J. The short-term effects of wood-ash amendment on forest soils. Water Air Soil Pollut. 1990, 49, 299-314. [CrossRef]

220. Ohno, T.; Erich, M.S. Effect of wood ash application on soil pH and soil test nutrient levels. Agric. Ecosyst. Environ. 1990, 32, 223-239. [CrossRef]

221. Meiwes, K.J. Application of lime and wood ash to decrease acidification of forest soils. Water Air Soil Pollut. 1995, 85, 143-152. [CrossRef]

222. Kahl, J.S.; Fernandez, I.J.; Rustad, L.E.; Peckenham, J. Threshold application rates of wood ash to an acidic forest soil. Am. Soc. Agron. 1996, 25, 220-227. [CrossRef]

223. Williams, T.M.; Hollis, C.A.; Smith, B.R. Forest soil and water chemistry following bark boiler bottom ash application. J. Environ. Qual. 1996, 25, 955-961. [CrossRef]

224. Kopecky, M.J.; Meyers, N.L.; Wasko, W. Using industrial wood ash as a soil amendment. Magnes. Res. 1995, 1, $240-440$.

225. Jacobson, S.; Gustafsson, L. Effects on ground vegetation of the application of wood ash to a Swedish Scots pine stand. Basic Appl. Ecol. 2001, 2, 233-241. [CrossRef]

226. Lerner, B.R.; Utzinger, J.D. Wood ash as soil liming material. HortScience 1986, 21, 76-78.

227. Campbell, A.G. Recycling and disposing of wood ash. TAPPI J. 1990, 73, 141-146.

228. Wiklund, J. Effects of Wood Ash on Soil Fertility and Plant Performance in Southwestern Kenya. Ph.D. Thesis, Swedish University of Agricultural Sciences, Uppsala, Sweden, 2017.

229. Clapham, W.M.; Zibilske, L.M. Wood ash as a liming amendment. Commun. Soil Sci. Plant Anal. 1992, 23, 1209-1227. [CrossRef]

230. Muse, J.K.; Mitchell, C.C. Paper mill boiler ash and lime by-products as soil liming materials. Agron. J. 1995, 87, 432-438. [CrossRef]

231. Sakthivel, S.R.; Tilley, E.; Udert, K.M. Wood ash as a magnesium source for phosphorus recovery from source-separated urine. Sci. Total Environ. 2012, 419, 68-75. [CrossRef]

232. Steenari, B.M.; Karlsson, L.G.; Lindqvist, O. Evaluation of the leaching characteristics of wood ash and the influence of ash agglomeration. Biomass Bioenergy 1999, 16, 119-136. [CrossRef]

233. Scheepers, G.P.; du Toit, B. Potential use of wood ash in South African forestry: A review. South. For. J. For. Sci. 2016, 78, 255-266. [CrossRef]

234. Chang, A.C.; Lund, L.J.; Page, A.L.; Warneke, J.E. Physical properties of fly ash-amended soils. Am. Soc. Agron. 1977, 6, 267-270. [CrossRef]

235. Jansone, B.; Samariks, V.; Okmanis, M.; Klavina, D.; Lazdina, D. Effect of High Concentrations of Wood Ash on Soil Properties and Development of Young Norway Spruce (Picea abies (L.) Karst) and Scots Pine (Pinus sylvestris L.). Sustainability 2020, 12, 9479. [CrossRef]

236. Sharifi, M.; Cheema, M.; McVicar, K.; LeBlanc, L.; Fillmore, S. Evaluation of liming properties and potassium bioavailability of three Atlantic Canada wood ash sources. Can. J. Plant Sci. 2013, 93, 1209-1216. [CrossRef]

237. Baon, J.B. Use of plant derived ash as potassium fertilizer and its effects on soil nutrient status and cocoa growth. J. Trop. Soils 2009, 14, 185-193.

238. Füzesi, I.; Heil, B.; Kovács, G. Effects of wood ash on the chemical properties of soil and crop vitality in small plot experiments. Acta Silv. Lignaria Hung. 2015, 11, 55-64. [CrossRef]

239. Thomas, S.; Anand, A.; Chinnusamy, V.; Dahuja, A.; Basu, S. Magnetopriming circumvents the effect of salinity stress on germination in chickpea seeds. Acta Physiol. Plant. 2013, 35, 3401-3411. [CrossRef] 
240. Machado, R.M.A.; Serralheiro, R.P. Soil salinity: Effect on vegetable crop growth. Management practices to prevent and mitigate soil salinization. Horticulturae 2017, 3, 30. [CrossRef]

241. Pandey, V.C.; Singh, N. Impact of fly ash incorporation in soil systems. Agric. Ecosyst. Environ. 2010, 136, 16-27. [CrossRef]

242. Ram, L.C.; Masto, R.E. Fly ash for soil amelioration: A review on the influence of ash blending with inorganic and organic amendments. Earth-Sci. Rev. 2014, 128, 52-74. [CrossRef]

243. Singh, R.; Singh, D.P.; Kumar, N.; Bhargava, S.K.; Barman, S.C. Accumulation and translocation of heavy metals in soil and plants from fly ash contaminated area. J. Environ. Biol. 2010, 31, 421-430.

244. Ferreira, C.; Ribeiro, A.; Ottosen, L. Possible applications for municipal solid waste fly ash. J. Hazard. Mater. 2003, 96, 201-216. [CrossRef]

245. Sohi, S.; Lopez-Capel, E.; Krull, E.; Bol, R. Biochar, climate change and soil: A review to guide future research. CSIRO Land Water Sci. Rep. 2009, 5, 17-31.

246. Saletnik, B.; Zagula, G.; Bajcar, M.; Czernicka, M.; Puchalski, C. Biochar and biomass ash as a soil ameliorant: The effect on selected soil properties and yield of Giant Miscanthus (Miscanthus giganteus). Energies 2018, 11, 2535. [CrossRef]

247. Hale, S.E.; Nurida, N.L.; Mulder, J.; Sørmo, E.; Silvani, L.; Abiven, S.; Joseph, S.; Taherymoosavi, S.; Cornelissen, G. The effect of biochar, lime and ash on maize yield in a long-term field trial in a Ultisol in the humid tropics. Sci. Total Environ. 2020, 719, 137455. [CrossRef]

248. Alling, V.; Hale, S.E.; Martinsen, V.; Mulder, J.; Smebye, A.; Breedveld, G.D.; Cornelissen, G. The role of biochar in retaining nutrients in amended tropical soils. J. Plant Nutr. Soil Sci. 2014, 177, 671-680. [CrossRef]

249. Bieser, J.M.; Thomas, S.C. Biochar and high-carbon wood ash effects on soil and vegetation in a boreal clearcut. Can. J. For. Res. 2019, 49, 1124-1134. [CrossRef]

250. Masto, R.E.; Ansari, M.A.; George, J.; Selvi, V.A.; Ram, L.C. Co-application of biochar and lignite fly ash on soil nutrients and biological parameters at different crop growth stages of Zea mays. Ecol. Eng. 2013, 58, 314-322. [CrossRef]

251. Mohan, D.; Pittman Jr, C.U.; Bricka, M.; Smith, F.; Yancey, B.; Mohammad, J.; Steele, P.H.; Alexandre-Franco, M.F.; Gómez-Serrano, V.; Gong, H. Sorption of arsenic, cadmium, and lead by chars produced from fast pyrolysis of wood and bark during bio-oil production. J. Colloid Interface Sci. 2007, 310, 57-73. [CrossRef]

252. Mendez, A.; Gomez, A.; Paz-Ferreiro, J.; Gasco, G. Effects of sewage sludge biochar on plant metal availability after application to a Mediterranean soil. Chemosphere 2012, 89, 1354-1359. [CrossRef]

253. Wann, S.S.; Uehara, G. Surface charge manipulation in constant surface potential soil colloids: II. Effect on solute transport. Soil Sci. Soc. Am. J. 1978, 42, 886-888. [CrossRef]

254. Nkana, J.V.; Demeyer, A.; Verloo, M.G. Chemical effects of wood ash on plant growth in tropical acid soils. Bioresour. Technol. 1998, 63, 251-260. [CrossRef]

255. Hart, S.; Luckai, N. Charcoal function and management in boreal ecosystems. J. Appl. Ecol. 2013, 50, 1197-1206. [CrossRef]

256. Kolb, S.E.; Fermanich, K.J.; Dornbush, M.E. Effect of charcoal quantity on microbial biomass and activity in temperate soils. Soil Sci. Soc. Am. J. 2013, 73, 1173-1181. [CrossRef]

257. Qiu, Y.; Cheng, H.; Xu, C.; Sheng, G.D. Surface characteristics of crop-residue-derived black carbon and lead (II) adsorption. Water Res. 2008, 42, 567-574. [CrossRef]

258. Zinati, G.M.; Li, Y.C.; Bryan, H.H. Utilization of compost increases organic carbon and its humin, humic and fulvic acid fractions in calcareous soil. Compos. Sci. Util. 2001, 9, 156-162. [CrossRef]

259. Evanylo, G.; Sherony, C.; Spargo, J.; Starner, D.; Brosius, M.; Haering, K. Soil and water environmental effects of fertilizer-, manure-, and compost-based fertility practices in an organic vegetable cropping system. Agric. Ecosyst. Environ. 2008, 127, 50-58. [CrossRef]

260. Tejada, M.; Garcia, C.; Gonzalez, J.L.; Hernandez, M.T. Use of organic amendment as a strategy for saline soil remediation: Influence on the physical, chemical and biological properties of soil. Soil Biol. Biochem. 2006, 38, 1413-1421. [CrossRef]

261. Brewer, C.E.; Chuang, V.J.; Masiello, C.A.; Gonnermann, H.; Gao, X.; Dugan, B.; Davies, C.A. New approaches to measuring biochar density and porosity. Biomass Bioenergy 2014, 66, 176-185. [CrossRef]

262. Hardie, M.; Clothier, B.; Bound, S.; Oliver, G.; Close, D. Does biochar influence soil physical properties and soil water availability? Plant Soil 2014, 376, 347-361. [CrossRef]

263. Downie, A.; Crosky, A.; Munroe, P. Physical properties of biochar. In Biochar for Environmental Management: Science and Technology; Lehmann, J., Joseph, S., Eds.; Earthscan: London, UK, 2009; pp. 13-32.

264. Gao, X.; Driver, L.E.; Kasin, I.; Masiello, C.A.; Pyle, L.A.; Dugan, B.; Ohlson, M. Effect of environmental exposure on charcoal density and porosity in a boreal forest. Sci. Total Environ. 2017, 592, 316-325. [CrossRef] [PubMed]

265. Gray, M.; Johnson, M.G.; Dragila, M.I.; Kleber, M. Water uptake in biochars: The roles of porosity and hydrophobi-city. Biomass Bioenergy 2014, 61, 196-205. [CrossRef]

266. Tryon, E.H. Effect of charcoal on certain physical, chemical, and biological properties of forest soils. Ecol. Monogr. 1948, 18, 81-115. [CrossRef]

267. Eliche-Quesada, D.; Felipe-Sesé, M.A.; López-Pérez, J.A.; Infantes-Molina, A. Characterization and evaluation of rice husk ash and wood ash in sustainable clay matrix bricks. Ceram. Int. 2017, 43, 463-475. [CrossRef]

268. Abel, S.; Peters, A.; Trinks, S.; Schonsky, H.; Facklam, M.; Wessolek, G. Impact of biochar and hydrochar addition on water retention and water repellency of sandy soil. Geoderma 2013, 202, 183-191. [CrossRef] 
269. Karhu, K.; Mattila, T.; Bergström, I.; Regina, K. Biochar addition to agricultural soil increased CH4 uptake and water holding capacity-Results from a short-term pilot field study. Agric. Ecosyst. Environ. 2011, 140, 309-313. [CrossRef]

270. Santalla, M.; Omil, B.; Rodríguez-Soalleiro, R.; Merino, A. Effectiveness of wood ash containing charcoal as a fertilizer for a forest plantation in a temperate region. Plant Soil 2011, 346, 63-78. [CrossRef]

271. Hannam, K.D.; Venier, L.; Hope, E.; McKenney, D.; Allen, D.; Hazlett, P.W. AshNet: Facilitating the use of wood ash as a forest soil amendment in Canada. For. Chron. 2017, 93, 17-20. [CrossRef]

272. Tran, Q.T.; Maeda, M.; Oshita, K.; Takaoka, M. Phosphorus release from cattle manure ash as soil amendment in laboratory-scale tests. Soil Sci. Plant Nutr. 2017, 63, 369-376. [CrossRef]

273. Mbah, C.N.; Dada, O.A.; Okoro, T.N.; Ifejimalu, A. Use of Poultry Droppings and Wood Ash as Soil Amendment and its Effect on Soil Properties and Yield of Maize. Int. J. Adv. Sci. Res. Eng. 2018, 4, 74-78. [CrossRef]

274. Strelko, V., Jr.; Malik, D.J.; Streat, M. Characterisation of the surface of oxidised carbon adsorbents. Carbon 2002, $40,95-104$. [CrossRef] 